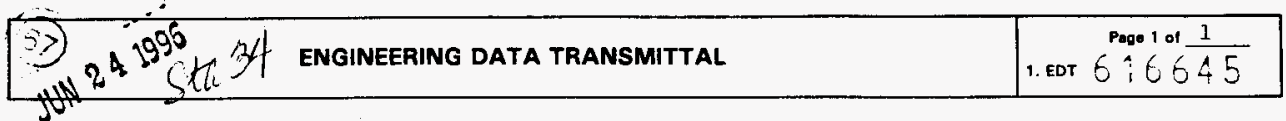

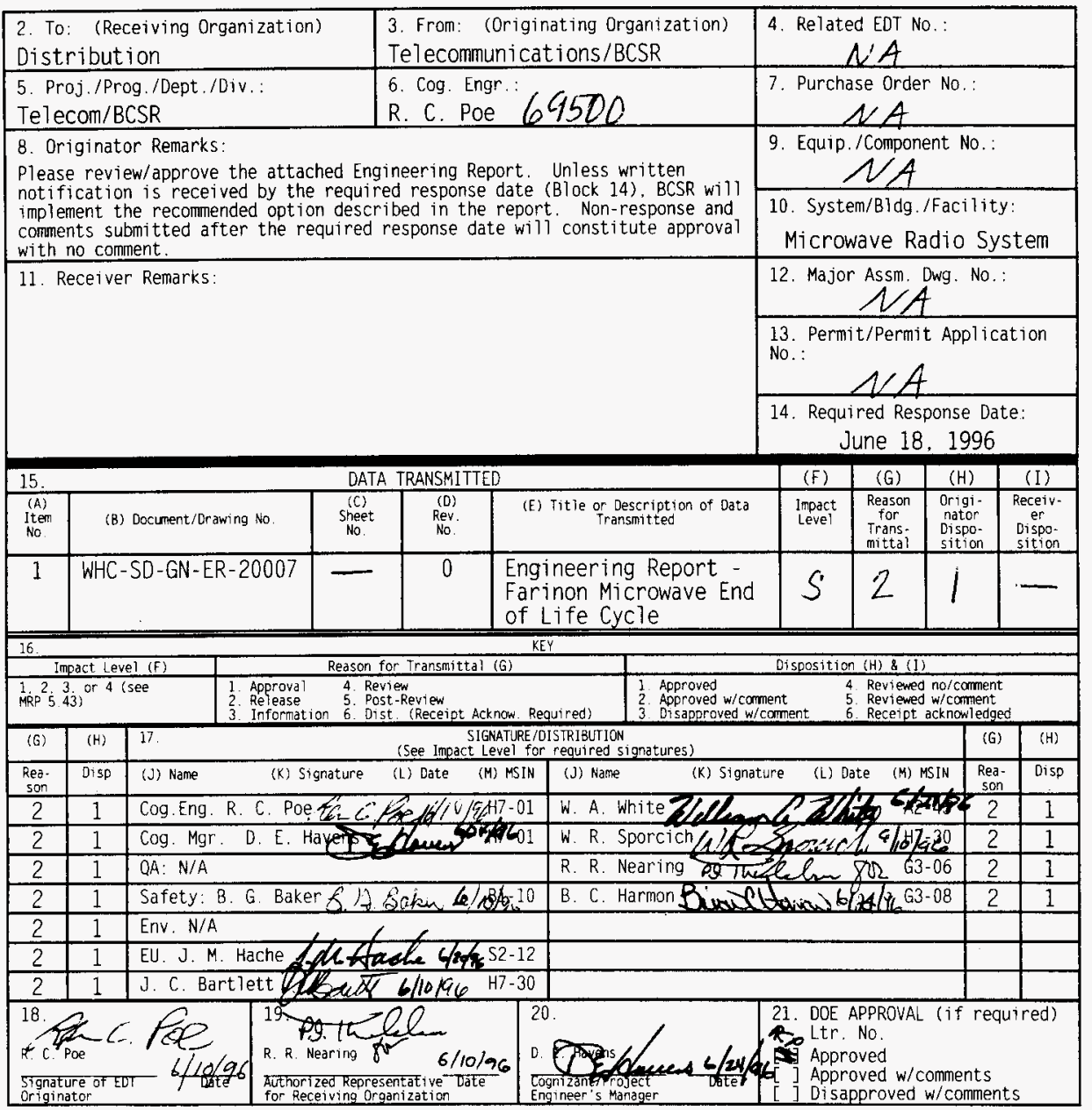

BD-7400-172-2 (07/91) GEF097 


\title{
Farinon Microwave End of Life Cycle
}

\author{
R. C. Poe
}

BCSR, Richland, WA 99352

U.S. Department of Energy Contract DE-AC06-87RL10930

$\begin{array}{lll}\text { EDT/ECN: } & 616645 & \text { UC: } 606 \\ \text { Org Code: } & 69500 & \text { Charge Code: } \\ \text { B\&R Code: } & \text { YN0100000 } & \text { Tota1 Pages: } 58\end{array}$

Key Words: Microwave Radio, SCADA

Abstract: This engineering report evaluates alternatives for the replacement of the Farinon microwave radio system. The system is beyond its expected life cycle and has decreasing maintainability. Principal applications supported by the Farinon system are two electrical utility monitor and control systems the Integrated Transfer Trip System (ITTS) and the Supervisory Control and Data Acquisition (SCADA) system.

TRADEMARK DISCLAIMER. Reference herein to any specific commercial product. process. or service by trade name, trademark, manufacturer. or otherwise, does not necessarjiy constitute or imply its endorsement, recomitendation, or favoring by the United States Government or any agency thereof or its contractors or subcontractors.

Printed in the United States of America. To obtain copies of this document, contact: WHC/BCS Document Control Services. P.0. Box 1970. Mailstop H6-08, Richland WA 99352. Phone (509) 372-2420; Fax (509) 376-4989.
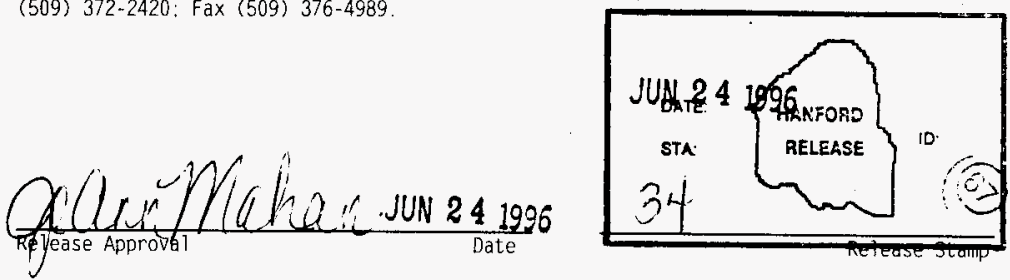

\section{Approved for Public Release}


TABLE OF CONTENTS

Page

TERMS

iii

EXECUTIVE SUMMARY $\ldots \ldots \ldots \ldots \ldots \ldots \ldots \ldots \ldots \ldots \ldots$ iv

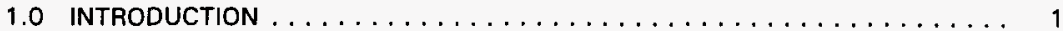

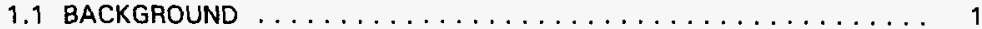

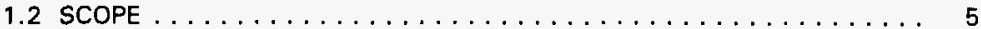

2.0 RECOMMENDATIONS AND CONCLUSIONS $\ldots \ldots \ldots \ldots \ldots \ldots$

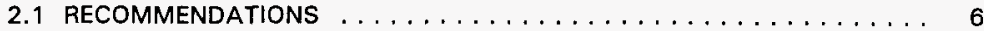

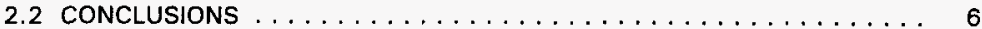

3.0 CURRENT MAINTENANCE STATUS $\ldots \ldots \ldots \ldots \ldots \ldots$

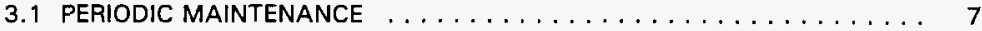

3.2 EMERGENT MAINTENANCE $\ldots \ldots \ldots \ldots \ldots \ldots \ldots \ldots$

4.0 DESCRIPTION OF ALTERNATIVES $\ldots \ldots \ldots \ldots \ldots \ldots \ldots \ldots \ldots$

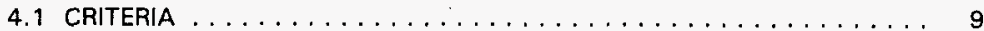

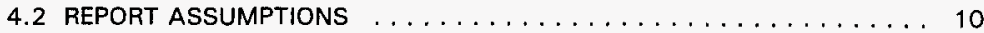

4.3 ALTERNATIVES ......................... 12

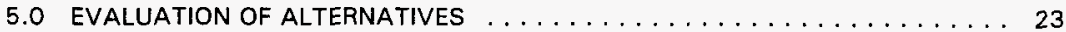

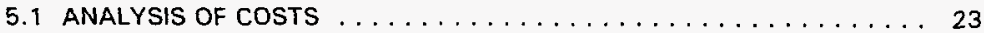

5.2 EVALUATION OF NON-COST FACTORS $\ldots \ldots \ldots \ldots \ldots \ldots \ldots \ldots$

5.3 CAPITAL ASSET MANAGEMENT PROCESS . . . . . . . . . . . . 24

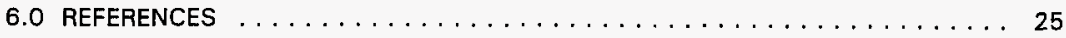

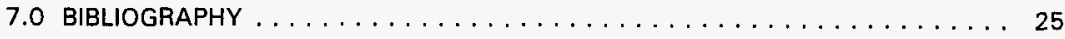

\section{LIST OF FIGURES}

Figure 1 - Farinon Microwave System ........................... Page

Figure 2 - Alternative $\mathrm{C}$ Modifications to SCADA $\ldots \ldots \ldots \ldots \ldots \ldots \ldots \ldots \ldots$

Figure 3 - Alternative $\mathrm{C}$ Modifications to ITTS $\ldots \ldots \ldots \ldots \ldots \ldots$ 


\section{LIST OF TABLES}

Table I - Advantages and Disadvantages of Alternative A Page

Table II - Advantages and Disadvantages of Alternative B $\ldots \ldots \ldots \ldots \ldots \ldots$

Table III - Comparison of Technical and Operational Characteristics . . . . . . . . . . . 19

Table IV - Advantages and Disadvantages of Alternative $C \ldots \ldots \ldots \ldots \ldots$

Table $V$ - Cost Analysis Summary (in $\$ K) \ldots \ldots \ldots \ldots \ldots \ldots$

Table VI - Summary of Non-cost Factors . . . . . . . . . . . . . . . . 23

Table VII - Capital Asset Management Analysis . . . . . . . . . . . . . . . . . . . . 24

\section{Appendices:}
A. Data and Computations
B. Cost Analysis Details
C. Capital Asset Management Process Analysis

\section{TERMS}

$\begin{array}{ll}\text { BCSR } & \text { Boeing Computer Services Richland } \\ \text { BPA } & \text { Bonneville Power Administration } \\ \text { COE } & \text { U.S. Army Corps of Engineers } \\ \text { DOE } & \text { U.S. Department of Energy } \\ \text { HAN } & \text { Hanford Area Network } \\ \text { HLAN } & \text { Hanford Local Area Network } \\ \text { ITTS } & \text { Integrated Transfer Trip System } \\ \text { IVDTS } & \text { Integrated Voice Data Telecommunications System } \\ \text { NTIA } & \text { National Telecommunications Information Administration } \\ \text { SCADA } & \text { Supervisory Control and Data Acquisition System } \\ \text { SONET } & \text { Synchronous Optical Network } \\ \text { WHC } & \text { Westinghouse Hanford Company }\end{array}$




\section{EXECUTIVE SUMMARY}

\section{SITUATION}

The Farinon Microwave System (Farinon System) is at end of life and is the primary telecommunications system for the Hanford Site's electrical grid and fault protection signalling applications.

This situation is compounded with an imminent failure situation, due to the non-availability of replacement parts. The manufacturer of the Farinon System no longer produces repair parts for the system, nor are any available from other sources. All Farinon replacement parts have been exhausted. The current Mean-time between failure (MTBF) is $2400 \mathrm{hrs}$. The Farinon system failure would jeopardize the safe management of the Hanford electrical distribution grid. The next replacement component failure could result in the following system applications impacts:

- Utility Substation Transfer Trip. Seriously jeopardizes transmission line protection. Damage to site plant and regional power production systems.

- Supervisory Control and Data Acquisition (SCADA) applications. Significantly delays troubleshooting on transmission lines, causing significant Site outages and equipment damage.

The long lead time for repair and return of parts combined with the current failure rate drives the likelihood of a catastrophic failure. Currently, the long lead time is compensated for by replacing the malfunctioning component with a spare. However, if the spare should fail before the part is returned, there would be no further backup for the system. Of the maintenance events in the repair log (Appendix A), 22.4\% required a turn-around time for parts that exceeded the mean time between failures ( 90 days). This trend indicates a one-in-five probability for a catastrophic failure.

While these systems could be transferred to the Integrated Voice Data Telecommuncations System (IVDTS) fiber optic backbone, it does not have the redundancy necessary for the support of the ITTS. A related project, L-273, Infrastructure Fiber Loop, Inner Area would provide an alternate telecommunications path for the Site critical telecommunications systems should the primary fiber optic cable fail. 


\section{TARGET}

This study evaluates several alternatives for replacing the Farinon Microwave System. The alternatives are evaluated using the primary criteria of safety, operational effectiveness, maintainability, cost, and life cycle. Three alternatives were evaluated for supporting the telecommunications services currently provided by the Farinon System.

Alternative A Do Nothing.

Alternative B Upgrade the Microwave System.

Alternative C Transfer to the Upgraded Telecommunications Backbone System.

\section{PROPOSAL}

The recommended alternative transfers the applications using the Farinon Microwave System to the telecommunications infrastructure. SCADA signalling will be connected into -the fiber optic backbone transporting carrier between Site areas. Historical records show a 100 percent availability of the fiber optic backbone. The ITTS signalling on will be placed on dedicated fiber optic connections.

The implementation cost for the proposed solution is $\$ 239,100$. The life cycle cost for this solution is $\$ 261,600$ with 5 years to payback over existing system.

The recommended alternative assumes the L-273 Fiber Loop Project will be implemented to support this proposed alternative. 
WHC-SD-GN-ER-20007, Rev. 0

\subsection{INTRODUCTION}

This engineering report evaluates the replacement of the telecommunications services currently supplied by the Farinon Microwave System (Farinon System). The Farinon System has reached the end of its intended design life and no longer provides reliable telecommunications.

The Farinon System is owned, operated, and maintained by the Department of Energy (DOE) in conjunction with the Bonneville Power Administration (BPA). It serves as a telecommunications backbone for the Hanford Site electrical transmission grid control signal, status data, and alarm communication. It also links electrical grid protection data between the DOE electrical transmission grid and the BPA Electrical Transmission Grid through a shared interface.

\subsection{BACKGROUND}

\subsubsection{Operational Area of Farinon System}

In 1943 the United States Army Corps of Engineers (COE) selected an area of about 1,450 square kilometers (560 square miles) in the southeastern portion of the state of Washington for producing nuclear materials in support of the Unites States' effort in World War II. Until the end of the Cold War, the Hanford Site was dedicated to the production of nuclear materials, electricity, diverse research, and waste management activities. Since the end of the Cold War, the mission has been focused on environmental remediation of the Hanford Site.

Hanford facilities were first built and operated by the COE as part of the Manhattan Project. The Site and its facilities have since been administrated by the Atomic Energy Commission and its successors, the Energy Research and Development Administration (ERDA) and the DOE.

\subsubsection{Original Functional Requirement}

1.1.2.1 Electrical Distribution Grid Control. Extensive telecommunication infrastructure and electrical distribution grid systems were created to support communications and electrical services at the Hanford Site. Federal and Hanford Site regulations require that electrical distribution grid systems monitor switching and status control, isolate line faults, and protect the Hanford and BPA electrical distribution grids. The Farinon System provides the backbone for data communication between the Hanford Site electrical substations and the Bonneville Power Administration's (BPA) electrical distribution system. 


\subsubsection{Farinon Microwave System Description}

1.1.3.1 Supported User Systems. The Farinon System was implemented to transport Supervisory Control and Data Acquisition System (SCADA) and Integrated Transfer Trip System (ITTS) signals. SCADA and ITTS switch and status control, isolate line faults, and protect the Hanford and BPA electrical distribution grids. Its major components are Farinon analog radios and Lenkurt ancillary equipment (i.e., multiplexers, power supplies, etc.). The Farinon System transports this information between Gable Mountain Radio Site (Gable Mountain) and the Hanford Electrical Substations at 100B, 100KW, 100D, and $251 \mathrm{~W}$. The Gable Mountain site provides high ground for line-of-sight communications between all substations.

- SCADA. The SCADA system monitors, provides status, and alarm signaling to allow the Hanford Electrical Dispatcher to change electrical power routings remotely throughout the seven primary substations and four secondary substations of Hanford's electrical power distribution system. The SCADA system utilizes microwave systems and various fiber optic and twisted pair telecommunication lines to communicate across this system.

The Farinon System currently carries dedicated SCADA circuits which communicate data from Gable Mountain to the 251W Substation. Some data is also carried from other Areas to Gable Mountain on the Collins Microwave System where it is then transferred to the $251 \mathrm{~W}$ Substation on the Farinon Microwave system. The data can also be sent from the $251 \mathrm{~W}$ Substation to the other Areas utilizing the same circuits.

- ITTS. The ITTS is a monitoring system application that acts as the primary means of providing protection to the Hanford Site 230 kilovolt (KV) electrical transmission system. The DOE required the BPA to supply the ITTS to ensure the reliable operation and protection of the Hanford Site $230 \mathrm{kV}$ electrical transmission system. The ITTS provides high speed clearing $(3$ to 5 cycles or 60 to 80 milliseconds) of electrical fauts on the Hanford $230 \mathrm{KV}$ electrical transmission system. The ITTS utilizes the Farinon System and a $900 \mathrm{Mhz}$ radio system to relay signals from the four protective relays that currently protect the transmission lines.

1.1.3.2 Farinon System Configuration. The Farinon System use two associated links to complete the connectivity requirements. The two systems are physically connected through a hardwired interface at the Gable Mountain Facility.

- Gable Mountain Link. A separate $900 \mathrm{MHZ}$ radio system provides a point to point circuit connecting the BPA ASHE Substation, located near the Washington Public Power Supply System Plant No. 2 site, to the Farinon ring, located at the Gable Mountain radio facility.

- BPA Microwave Link. The ASHE Substation is connected to the Midway 
Substation located northwest of the Hanford Site by the BPA microwave system. The substation terminals combine system monitoring data, perform system switching, and to locate and isolate system faults for Hanford's electrical distribution system.

Figure 1 shows the physical locations for the Farinon System, the $900 \mathrm{MHZ}$ radio to ASHE Substation, and BPA's microwave connection between ASHE and Midway Substations.

1.1.3.3 Service Telephone. The Farinon System supplies a voice channel that allows maintenance personnel to communicate with each other directly where the equipment is placed at each substation. The voice channel is common to each microwave installation allowing maintenance and operations personnel to communicate when telephones are not available.

\subsubsection{MANDATED FREQUENCY CHANGE}

A portion of the Farinon System operates in the 1710-1755 megahertz frequency band. The National Telecommunications Information Administration (NTIA) has mandated that these frequencies be relocated to another frequency band by January 1, 2004. The Farinon System is not capable of conversion to another frequency and therefore, the system's radios will have to be replaced. Under the current NTIA mandates, the replacement frequency would still be designated "For Federal Government Use ONLY."

1 Rowlett, T; DOE Memorandum; Subject: Potential Interference Alert, August 22, 1995 , p. 1 


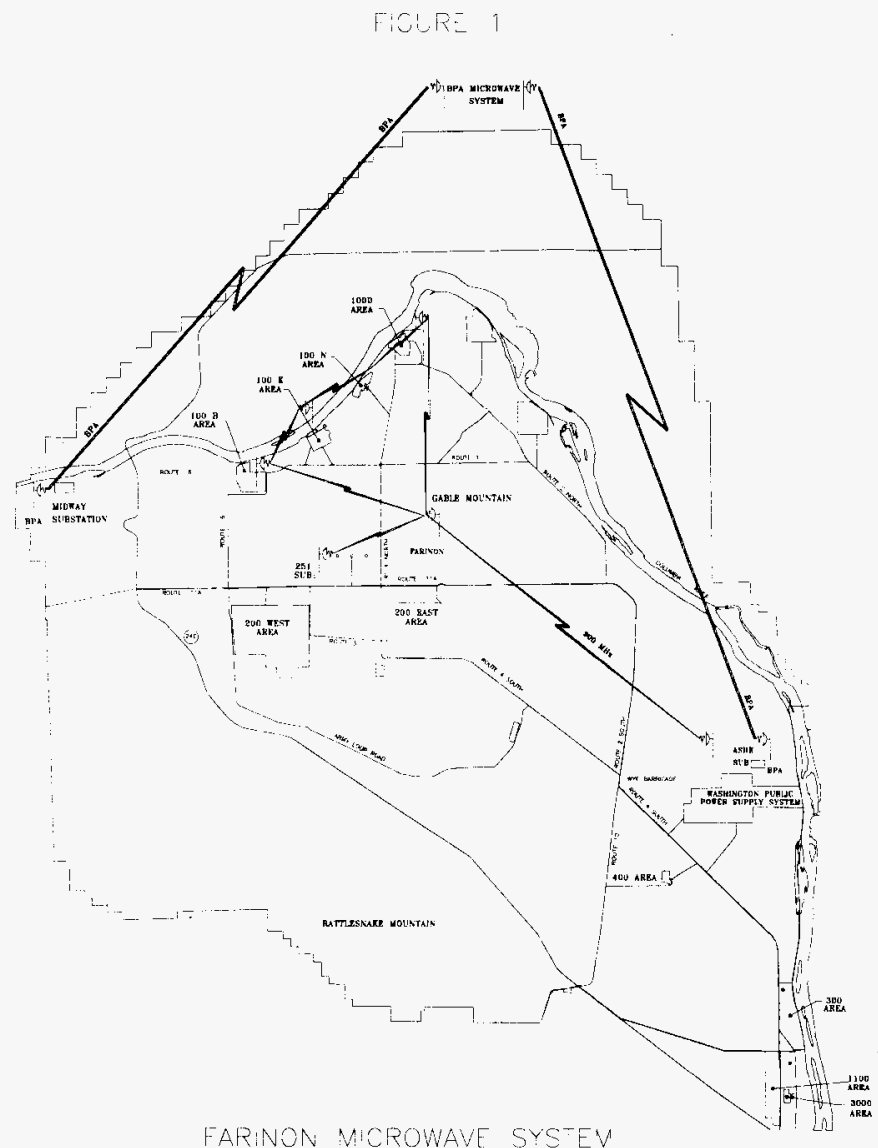




\subsubsection{Hanford Site Telecommunications Infrastructure}

The telecommunications infrastructure at the Hanford Site is unusually large. Unlike most systems of this size, the Hanford Site is connected by a vast network infrastructure that allows information to move across the Hanford Site instantaneously. Over 132 miles of optical fiber cable connect 187 Site facilities from the Federal Building to the 100 and 200 areas in the remotest parts of the Site. The optical fiber backbone employs current technology Synchronous Optica! Network (SONET) protocols for high speed, reliable telecommunications.

\subsection{SCOPE}

\subsubsection{Affected Telecommunications Systems and Facilities}

This study addresses the Farinon System (radio sites) and a small part of the Collins Microwave System which provides a physical ring configuration for circuit continuity. It evaluates alternatives addressing the transport vehicle, defines the present and future transport requirements, and recommends what transport system the site should pursue. The replacement system must be responsive to the end users and customers' needs and requirements while emphasizing safe, cost-effectiveness, and efficient utilization of resources.

\subsubsection{Affected Programs and Projects}

This study impacts the Site telecommunications infrastructure and electrical utilities within the Landlord program of projects. There are two end users for the data delivered on the Farinon System. The ICF Kaiser Company Electrical Utilities is the end user of the SCADA data and the BPA is the end user for the ITTS System data.

1.2.2.1 ICF Kaiser Requirements. The ICF Kaiser Company Electrical Utilities uses the SCADA data to monitor the configuration status of the electrical transmission grid. It is important to have the current configuration available to assure a safe working environment is maintained. The SCADA signals are also used to perform simple electrical transfer switching.

1.2.2.2 Bonneville Power Administration Requirements. BPA uses the ITTS System data to locate and isolate sections of transmission lines when a fault occurs. This protects the electrical equipment from potential harm. This system is also used to balance the BPA's electrical loads. Occurrences on the Farinon system could also impact other BPA facilities external to the Hanford Site. 


\subsection{RECOMMENDATIONS AND CONCLUSIONS}

\subsection{RECOMMENDATIONS}

The signaling interface supporting the SCADA and ITTS systems should be upgraded to interface with dedicated redundant circuits on the Site telecommunications infrastructure. Additional fiber optic cable would be installed to link the ITTS system into the Site infrastructure, and twisted pair copper cable would be installed to link the SCADA system. Terminal equipment would be installed to meet the required circuit parameters of the SCADA and ITTS systems.

\subsection{CONCLUSIONS}

The study established the need to continue transporting SCADA and ITTS signalling and other Farinon system circuits. Three alternatives were evaluated for supporting the telecommunications services currently provided by the Farinon System.

Alternative A Do Nothing.

Alternative B Upgrade the Microwave System.

Alternative C Transfer to the Upgraded Telecommunications Backbone System.

Alternative $\mathrm{C}$ satisfies the present and future requirements and is the most cost-effective in terms of life cycle. This alternative would supply a replacement transport system for the Farinon System that would have a high degree of reliability while meeting the requirements of the SCADA and ITTS Systems. 


\subsection{CURRENT MAINTENANCE STATUS}

Two aspects of Maintenance are considered when evaluating costs, reliability, and risks of a telecommunications system. The first is periodic maintenance, which is part of a planned preventative program. The second is emergent maintenance, typically caused by a physical failure of a component and results in an unplanned service outage.

\subsection{PERIODIC MAINTENANCE}

The Farinon System has a limited supply of spares and any alterations to the radio components may affect delicately-balanced system adjustments and parameters. Consequently, no periodic maintenance is performed on the radio systems under the existing conditions. However, this does not negate the existing requirement for periodic maintenance ${ }^{2}$ and must be considered in the evaluation of alternatives.

\subsection{EMERGENT MAINTENANCE}

\subsubsection{System Reliability}

As the Farinon System's components age, they become more prone to failures. "Federally owned fixed microwave systems in the 1710-1850 $\mathrm{MHZ}$ band [such as the Farinon System] have a useful life of 10 years." 3 The major components of the Farinon System were designed prior to their 1984 purchase date. The Farinon System is now operating in its thirteenth year, it will have to operate at least another one and a half years before an alternative can be provided. The average failure rate of the systems is four failures per year or 90 days between failures. The details of system maintenance events are shown in Appendix A.

\subsubsection{Manufacturer and Vendor Support}

Replacement parts for many critical system components have been discontinued by Harris since 1992, the firm which acquired manufacturing rights of the Farinon system. Third party vendors also have stopped fabricating parts for this system. Additionally, the parts which can be supported on a repair-and-return basis have an increasing turn-around time. The current average turn-around time for parts is 71 days. This increases the risk of a simple component failure turning into a major system failure due to unavailability of

\footnotetext{
2 DOE 4330.4B, Section 1, Paragraph 3.6

3 Brown, R; Spectrum Reallocation Final Report, February 1995, p. A-3
} 
WHC-SD-GN-ER-20007, Rev. 0

replacement parts. Appendix A shows details on trend data, critical parts and current availability.

\subsubsection{Probability of Catastrophic Failure}

\subsubsection{Cost of Replacement Parts}

Even before the manufacturer and third party vendors discontinued support of the Farinon System, part replacement costs had escalated significantly. For example, Power supply Part No. 18305 cost has increased in price by $350 \%$; $\$ 710$ in 1988 to $\$ 2501$ in 1995 . Over the past eleven years, this power supply has accounted for $43 \%$ (22 of the 51 ) of the reported component failures in the Farinon system. In the last three years, it has accounted for $75 \%(6$ of 8 ) of the reported component failures.

\subsubsection{Maintenance Labor Costs}

As systems age, labor costs for repairs, procuring parts, and component replacement increase as the frequency of component failure increases. DOE 4330.4B (Maintenance Management) also states that corrective maintenance is not used to extend the expected useful life of equipment. It is not an accepted practice to expend labor hours to offset the cost of replacement parts. 
WHC-SD-GN-ER-20007, Rev. 0

\subsection{DESCRIPTION OF ALTERNATIVES}

\subsection{CRITERIA}

This section establishes the criteria by which each alternative will be evaluated. The actual requirements for the function provided by the Farinon System are more extensive, but those criteria that were equal for all alternatives were eliminated as trivial for the purposes of this analysis.

\subsubsection{Safety}

4.1.1.1 General Safety. The alternative shall not degrade the safety of the Site operating environment.

4.1.1.2 Equipment Safety. The alternative will prevent damage to both on-site and offsite equipment.

4.1.1.3 Personnel Safety. The alternative will not adversely affect both on-site and offsite personnel safety.

\subsubsection{Operational Effectiveness}

4.1.2.1 Hanford Site Operations and Services. The alternative shall not negatively impact Site operations or the availability of Site services.

4.1.2.2 Radio Frequency Spectrum Availability. The alternative shall not require radio frequency bands that are not available for use on the Site. This includes all known or projected future availability of frequencies.

4.1.2.3 SCADA Criteria. The alternative shall support the 14 total circuits required for all of the SCADA functions located throughout the Hanford Site back to the $251 \mathrm{~W}$ Substation. The tones used to monitor and control the system do not require either physical or system redundant communication capability.

4.1.2.4 ITTS Criteria. The alternative shall support four circuits dedicated to the transmission of the ITTS data between the Hanford Site and the ASHE Substation. The ITTS closely interfaces with the BPA electrical transmission system. Therefore, the circuits and interface equipment supporting the ITTS have very specific technical requirements. The technical and operational requirements for the ITTS system and its associated circuits were agreed upon by DOE and $\mathrm{BPA}^{4}$ and are detailed in Appendix A. The BPA requires that the support system for the ITTS to have a reliability of greater than $99.98 \%$.

4 DOE-BPA Letter of Agreement, November 23, 1994. 
WHC-SD-GN-ER-20007, Rev. 0

\subsubsection{Maintainability}

4.1.3.1 Maintenance Costs. The alternative shall provide for the maintenance and service of the installed systems at an annual cost of less than 10 per cent of replacement cost.

4.1.3.2 System Design and Configuration. The alternative shall meet current state-of-thetechnology in its design and configuration. The alternative shall not require extensive upgrade in less than five years. The system configuration shall optimize the technical advantages of equipment components.

4.1.3.3 Parts Availability. The alternative shall provide long-range parts and component availability. As far as possible, the alternative will not use repair parts and replacement components specific to a single vendor.

4.1.3.4 Maintenance Policy and Procedures. The alternative shall meet the requirements of established policy and procedures ${ }^{5}$.

\subsubsection{Cultural Criteria}

The Gable Mountain cultural issues are also considered related to the evaluation of the alternatives. The alternative shall minimize cultural, environmental, and property impacts on Gable Mountain.

\subsection{REPORT ASSUMPTIONS}

\subsubsection{Cost Assumptions}

4.2.1.1 Support from Project L-273. The cost analysis for this report is based on the L273 Fiber Loop Project being performed as it is currently planned. Placing fiber optic cable in several locations is credited as a cost avoidance to the L273 Project.

4.2.1.2 Life Cycle Analysis Assumptions. Several cost assumptions were made in performing the Life cycle cost analysis on the alternatives. These assumptions are detailed in the cost analysis summary page in Appendix B.

\subsubsection{Technical Assumptions}

4.2.2.1 System Reliability. The risk of major system failure is increasing as components exceed their design life cycle expectations. Allowing the system to remain in its current configuration may cause a non-recoverable system failure to occur.

5 DOE $4330.4 B$ 
4.2.2.2 Systems Maintenance. The turn-around time for maintenance of the Farinon System is increasing as the equipment is deteriorating with age and replacement parts are becoming unavailable.

4.2.2.3 Operation of $100 \mathrm{~B}$ and 100D Substations. The discontinuing use of the SCADA on the $100 B$ and $100 D$ susbstations is currently under study. However, for the purposes of this study, it will be assumed that the $100 \mathrm{~B}$ and100D substations shall remain in operation.

\subsubsection{Operational Assumptions}

4.2.3.1 Relay Support. There are four relays requiring ITTS support and are located between: the ASHE Substation and the $251 \mathrm{~W}$ Substation; the ASHE Substation and the $151 \mathrm{KW}$ Substation; the Midway Substation and the $151 \mathrm{KW}$ Substation; and the Midway Substation and the $251 \mathrm{~W}$ Substation.

4.2.3.2 System Expansion. There are two additional substations planned to be added to the Hanford grid at $200 E$ and $200 \mathrm{~W}$. These are required to be added to the SCADA System when they are constructed. Therefore, the alternatives need to consider expansion capability as a mandatory requirement.

\subsubsection{Policy and Regulatory Assumptions}

A portion of the frequency range utilized by the Farinon System is being vacated by the Federal Government on January 1, 2004 and the Farinon System is not capable of conversion to the new frequency range. 


\subsection{ALTERNATIVES}

This section contains the alternatives for upgrading or replacing the Farinon System. Each alternative is evaluated to the identified criteria. This report identifies the alternatives which offer the most value-added approach for continued support of the applications now utilizing the Farinon System.

\subsubsection{Unfeasible Alternatives}

All alternatives were evaluated for feasibility. The following alternatives were evaluated and dismissed as unfeasible:

4.3.1.1 Discontinue the Applications. The ITTS and SCADA circuits now supported by the Farinon System would be discontinued and the existing Farinon Microwave System would be excessed. This alternative is not feasible since discontinuing the SCADA and ITTS would create multiple safety hazard conditions. The absence of these systems could cause serious property, and equipment damage to systems even outside the Hanford Site, such as associated BPA power stations and power generating equipment and systems.

4.3.1.2 Transfer to Existing Telecommunication Systems. The channels supporting the SCADA and ITTS would be transferred to the existing twisted pair copper and fiber optic telecommunication infrastructure with associated modifications to the SCADA and ITTS interfaces. This alternative does not meet the reliability criteria ( $>99.98 \%$ availability) for the ITTS. 
WHC-SD-GN-ER-20007, Rev. 0

\subsubsection{Alternative A: Do Nothing}

The Farinon System would continue to function in the same configuration as it now exists. It currently supports the SCADA and ITTS applications.

4.3.2.1 Impact of Alternative A. Table I shows the advantages and disadvantages of Alternative A.

Table I - Advantages and Disadvantages of Alternative A

\begin{tabular}{|l|l|}
\hline \multicolumn{1}{|c|}{ ADVANTAGES } & \multicolumn{1}{c|}{ DISADVANTAGES } \\
\hline $\begin{array}{l}\text { SCADA and ITTS Criteria. The existing } \\
\text { SCADA has already been validated for the }\end{array}$ & $\begin{array}{l}\text { Equipment Safety. The location of } \\
\text { equipment on towers inherently exposes it } \\
\text { to safety risk. }\end{array}$ \\
\hline & $\begin{array}{l}\text { Persennel Safety. While the towers have } \\
\text { been modified to reduce safety risk, the } \\
\text { inherent nature of tower maintenance } \\
\text { exposes personnel to safety risk. }\end{array}$ \\
\hline & $\begin{array}{l}\text { Site Operations. As the maintainability of } \\
\text { the Farinon system degrades, the risk to } \\
\text { availability of site electrical utility } \\
\text { increases. }\end{array}$ \\
\hline $\begin{array}{l}\text { Erequency Availability. The Farinon } \\
\text { System would have to be replaced prior to } \\
\text { January 1, 2004 when a portion of its } \\
\text { frequency range is required to be relocated } \\
\text { by the National Telecommunications } \\
\text { Information Administration (NTIA). }\end{array}$ \\
\hline $\begin{array}{l}\text { Maintenance Costs. Special fabrication of } \\
\text { replacement parts would greatly exceed } \\
\text { the threshold (> 10\% replacement) of } \\
\text { annual maintenance costs. }\end{array}$ \\
\hline $\begin{array}{l}\text { Parts Availability. The long turnaround } \\
\text { time for all parts and non-availability of } \\
\text { certain critical parts cause an imminent risk } \\
\text { of a major system failure. }\end{array}$ \\
\hline
\end{tabular}

6 Rowlett, T; DOE Memorandum; Subject: Potential Interference Alert, August 22, 1995 , p. 1 


\begin{tabular}{|l|l|}
\hline \multicolumn{1}{|c|}{ ADVANTAGES } & \multicolumn{1}{|c|}{ DISADVANTAGES } \\
\hline & $\begin{array}{l}\text { Maintenance Policy. The system has } \\
\text { exceeded the recommended useful life of } \\
10 \text { vears for microwave systems. } \\
\text { Corrective maintenance should not be used } \\
\text { to extend the expected useful life of } \\
\text { equipment } \\
\text { expending labor hours to offset the cost of } \\
\text { replacement parts is not within policy } \\
\text { guidelines. }\end{array}$ \\
\hline & $\begin{array}{l}\text { Weather Factors. When the north slope of } \\
\text { Gable Mountain is covered with snow, the } \\
\text { Farinon System has experienced multi- } \\
\text { pathing of the two radio paths. }\end{array}$ \\
\hline \hline
\end{tabular}

4.3.2.2 Alternative Costs. The cost details for this alternative are shown in Appendix B

Annual Costs. Current system repair costs are approximately $\$ 13,400$ per year. To permit a fair comparison with the other alternatives, the cost of performing preventive maintenance is included, even though for reasons previously described, periodic maintenance is not being performed. The costs associated with maintaining the Farinon System are expected to increase approximately 20 percent per year due to equipment aging and the increased cost of replacement parts due to unavailability.

One-time Costs. Radio system must be replaced in FY 2002 in anticipation of the mandated frequency change. Equipment, labor and frequency coordination costs are associated with this requirement.

7 Brown, R; Spectrum Reallocation Final Report, February 1995, p. A-3

8 DOE 4330.4B, Attachment 1, Paragraph 2 
WHC-SD-GN-ER-20007, Rev. 0

\subsubsection{Alternative B: Upgrade the Microwave System}

The existing Farinon Microwave System which carries both the SCADA and ITTS circuits would be replaced with new radio equipment. This would require replacing the radio equipment at five locations: Gable Mountain, 251W Substation, 100B Substation, 100KE Substation, and 100D Substation. The 900 megahertz radio link connecting the Farinon System to the BPA's ASHE Substation would be retained as it now exists.

The ancillary equipment and two radios would have to be replaced at each location; one radio being required to transmit signals in a clockwise path and the other capable of transmitting signals in a counterclockwise path.

The replacement radio systems must be capable of communication with the BPA 900 megahertz system. The replacement radio systems must be capable simultaneously transmitting and receiving two tones. As each station has two radios, a total of ten Farinon radios will have to be replaced. The system could accommodate the planned substation expansion at the 200 East and 200 West Areas.

There is an increasing risk that frequencies will not be available for relocation. There are only a few available frequencies and there may not be available frequencies in the Hanford area. If a frequency could not be obtained, replacement of the microwave system would not be a valid alternative.

4.3.3.1 Impact of Alternative B. Table II shows the advantages and disadvantages of Alternative $\mathrm{B}$.

Table II - Advantages and Disadvantages of Alternative B

\begin{tabular}{|l|l|}
\hline \multicolumn{1}{|c|}{ ADVANTAGES } & \multicolumn{1}{c|}{ DISADVANTAGES } \\
\hline $\begin{array}{l}\text { Generaland Equipment Safety This } \\
\text { alternative has no high risk safety hazards } \\
\text { associated with its installation or operation. }\end{array}$ & $\begin{array}{l}\text { Personnel Safety. Tower Maintenance will } \\
\text { still be required, exposing personnel to } \\
\text { unnecessary risk. }\end{array}$ \\
\hline $\begin{array}{l}\text { SCADA/TTS Requirements This } \\
\text { aiternative meets all the SCADA and ITTS }\end{array}$ & $\begin{array}{l}\text { Frequency Availability There is an } \\
\text { increasing risk that frequencies will not be } \\
\text { available for relocation. New frequencies } \\
\text { will be required by this alternative. } \\
\text { Frequencies would not be usabie by } \\
\text { nongovernment companies. }\end{array}$ \\
\hline
\end{tabular}




\begin{tabular}{|l|l|}
\hline \multicolumn{1}{|c|}{ ADVANTAGES } & \multicolumn{1}{|c|}{ DISADVANTAGES } \\
\hline $\begin{array}{l}\text { Maintenance Costs. Estimated near the } \\
\text { threshold of } 10 \% .\end{array}$ & $\begin{array}{l}\text { System Design and Configuration. } \\
\text { Complicated to expand. Additional } \\
\text { antennas need to be added to existing } \\
\text { facilities. }\end{array}$ \\
\hline $\begin{array}{l}\text { Operational Requirements. This alternative } \\
\text { will meet Site operational requirements. }\end{array}$ & $\begin{array}{l}\text { Parts Availability. The alternative will } \\
\text { probably require procurement of parts from } \\
\text { a sole source. }\end{array}$ \\
\hline $\begin{array}{l}\text { Maintenance Policy. The alternative meets } \\
\text { the requirements of maintenance policies } \\
\text { and procedures. }\end{array}$ & $\begin{array}{l}\text { Cultural lssues. Placing of new equipment } \\
\text { on Gable Mountain would probably result } \\
\text { in some protest by affected cultural } \\
\text { groups. }\end{array}$ \\
\hline
\end{tabular}

4.3.3.2 Alternative Costs. Costs for implementing this alternative are:

Radio equipment purchase and installation TOTAL

$$
\begin{aligned}
& =\$ 211,000 \\
& =\$ 211,000
\end{aligned}
$$

Cost avoidance to $L 273$ Project $=\$ 0$

This includes the cost to obtain the frequency license assuming the frequency quoted is available. The cost may increase if the frequency is not available as it may affect the equipment price for another frequency. 


\subsubsection{Alternative C: Transfer to the Upgraded Telecommunications Backbone System}

This alternative would place the SCADA and ITTS Systems on the highly reliable Site telecommunication systems that meet their requirements while adding value to the Hanford Site. This will require routing new fiber optic cable between several sites but will add a high level of reliability to assure the electrical transmission grid is protected. This also adds greater protection to workers and equipment than the current system or other alternatives are capable of providing.

The existing Hanford Site hardwired telecommunication systems proposed in this report have demonstrated a reliability of greater than $99.98 \%$. To assure reliability of the ITTS redundant system paths will be supplied by dedicated duplicate fiber optic cable paths.

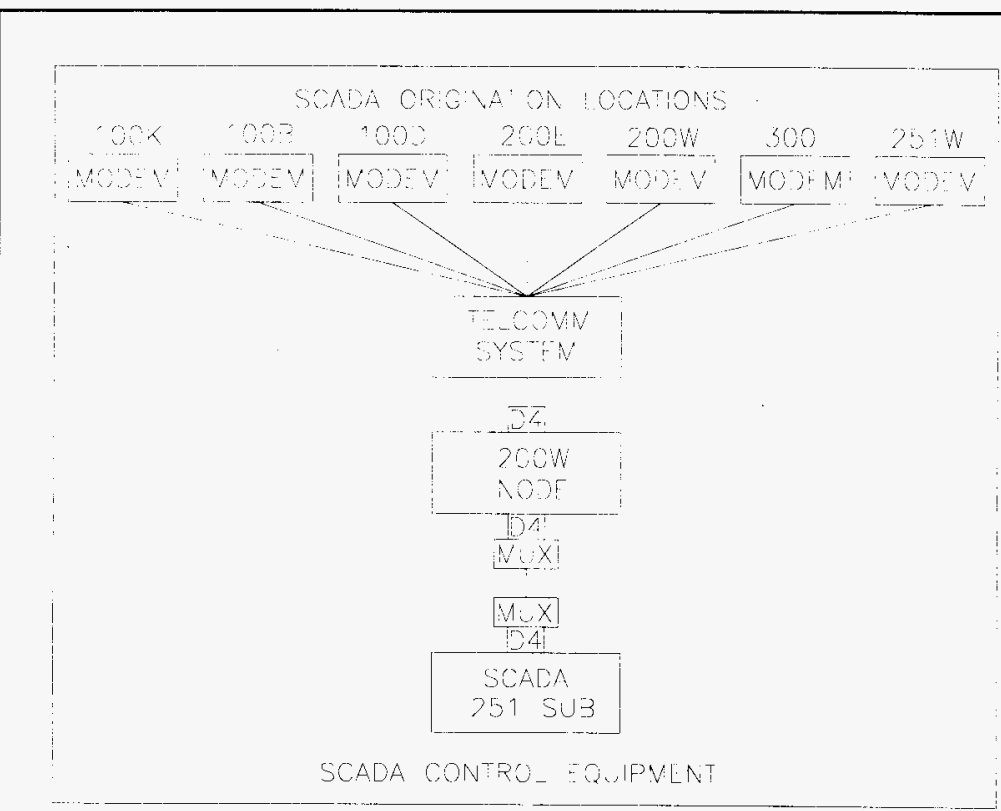

Figure 2 - Alternative C Modifications to SCADA 
4.3.4.1 Modifications to SCADA. SCADA equipment located at each substation facility would be connected to the SCADA equipment located at the $251 \mathrm{~W}$ Substation utilizing existing hardwired telephone circuits available at the facilities. At each location, the SCADA equipment would be connected to a modem by a twisted pair cable. Oniy those $\leftarrow$ links directly associated with the Farinon Microwave Radio will be changed. The local circuits linking the Farinon Microwave into each facility will remain as dedicated, hardwired private lines. These local links will be carried as special circuits on separate channels on the existing fiber optic backbone.

All circuits will be routed to Building $2220 \mathrm{~W}$, which will effectively take the place of the Gable Mountain Relay. From Building $2220 \mathrm{~W}$ the circuits will be connected via a new fiber multiplexer and a new fiber optic cable to the $251 \mathrm{~W}$ Substation, thus enhancing circuit reliability and stability. The fiber optic backbone has fully redundant circuit cards that automatically switch upon failure.

These design changes will increase the availability of the circuit by reducing repair down time and vulnerability to interference. The circuits will be specially designated as dedicated priority circuits that will be segregated from the standards switched circuits, reducing the risk of accidental tampering. As the existing criteria only requires 14 circuits, this aliows for 10 future circuits. (See Figure 2.) 
4.3.4.2 Existing SCADA Circuits. The existing circuits are passed to telephone tail circuits as they leave the microwave radio system. These circuits are wired through standard cable distribution systems at the terminal ends and at the Gable Mountain relay. At certain links they are transferred via the Lenkurt multiplexers to a shared channel system on the Collins Microwave system. Table III shows a comparison between the existing and proposed circuit characteristics.

Table III - Comparison of Technical and Operational Characteristics

\begin{tabular}{|l|l|l|}
\hline \multicolumn{1}{|c|}{ Characteristic } & \multicolumn{1}{|c|}{$\begin{array}{c}\text { Existing Microwave-Based } \\
\text { System }\end{array}$} & $\begin{array}{l}\text { Proposed Fiber Optic-Based } \\
\text { System }\end{array}$ \\
\hline Tail Circuits & On dedicated copper lines & No change \\
\hline Maintenance and service & On-call working hours & $\begin{array}{l}\text { 24-hour surveillance and } \\
\text { maintenance of circuits }\end{array}$ \\
\hline $\begin{array}{l}\text { Circuit Reliability/ } \\
\text { Availability }\end{array}$ & Near 100\% & $\begin{array}{l}\text { Emergency report log shows } \\
\text { no history of outages. } \\
100 \% \text { availability record. }\end{array}$ \\
\hline RFI/Microwave fade & Vulnerable & No vulnerability \\
\hline Privacy & $\begin{array}{l}\text { Parts of system subchannels } \\
\text { on the Collins Microwave }\end{array}$ & $\begin{array}{l}\text { Each channel is a dedicated } \\
\text { private protected circuit. }\end{array}$ \\
\hline Redundancy & $\begin{array}{l}\text { Automatic switching to } \\
\text { backup channel }\end{array}$ & $\begin{array}{l}\text { Automatic switching to } \\
\text { backup channel with } \\
\text { redundant circuit cards } \\
\text { incorporated into the } \\
\text { backbone multiplexers. }\end{array}$ \\
\hline $\begin{array}{l}\text { Mean time between } \\
\text { Failures }\end{array}$ & 90 days & $\begin{array}{l}\text { No recorded failures of fiber } \\
\text { optic infrastructure. }\end{array}$ \\
\hline
\end{tabular}

4.3.4.3 Modifications to ITTS. ITTS equipment located at the $251 \mathrm{~W}$ Substation and the $151 \mathrm{KW}$ Substation would be connected to the ITTS equipment located at the ASHE Substation utilizing new and existing fiber optic cable. At each location, the ITTS equipment would be connected to a multiplexer capable of accepting 24 dedicated circuits by a twisted pair cable. The multiplexers at the $251 \mathrm{~W}$ Substation and the $151 \mathrm{KW}$ Substation would be connected to two dedicated fiber optic cable circuits supplying system redundancy to the ASHE Substation. The following circuits are required by the existing criteria

- Ashe to Midway (2 circuits). 
- $\quad 100 \mathrm{~B}$ to Midway (2 circuits).

- $\quad 251 \mathrm{~W}$ to $100 \mathrm{D}(2$ circuits).

- One dial line

This alternative allows for additional circuits to accommodate future expansion.

The fiber cable routed between the facilities will be spliced together at each node allow transmission without being routed through any electronics except the multiplexers. This

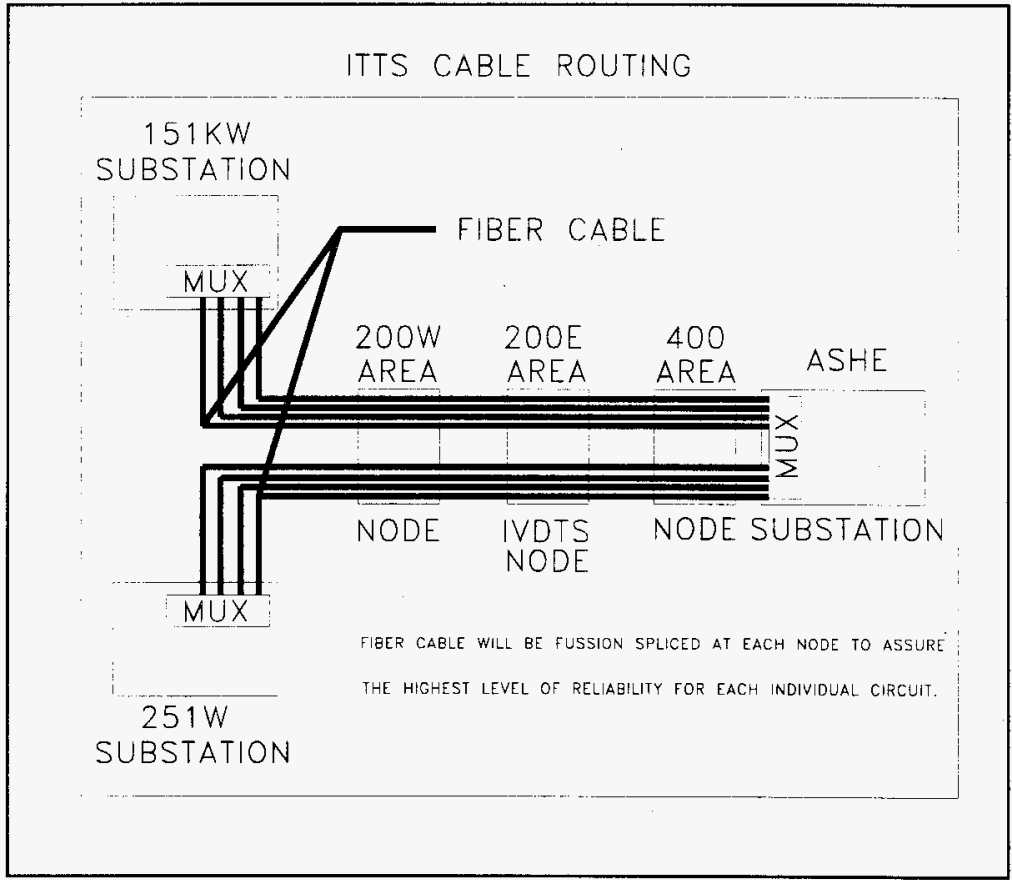

Figure 3 - Alternative C Modifications to ITTS

allows for high system reliability (See Figure 3 ). 
WHC-SD-GN-ER-20007, Rev. O

4.3.4.4 Impact of Alternative C. Table IV shows the advantages and disadvantages of Alternative $\mathrm{C}$.

Table IV - Advantages and Disadvantages of Alternative C

\begin{tabular}{|l|l|}
\hline \multicolumn{1}{|c|}{ ADVANTAGES } & \multicolumn{1}{|c|}{ DISADVANTAGES } \\
\hline $\begin{array}{l}\text { General Safety. This alternative has no } \\
\text { high risk safety hazards associated with its } \\
\text { installation or operation. }\end{array}$ & $\begin{array}{l}\text { SCADA Support. The cable infrastructure } \\
\text { to } 100 B \text { may require specialized equipment } \\
\text { to maintain circuit quality. }\end{array}$ \\
\hline $\begin{array}{l}\text { Site Operations. Meets all the } \\
\text { requirements for Site Operations }\end{array}$ & \\
\hline $\begin{array}{l}\text { Frequency Availability. This alternative is } \\
\text { not dependent on the Radio Frequency } \\
\text { Spectrum. }\end{array}$ & \\
\hline $\begin{array}{l}\text { SCADAlITS Requirements This } \\
\text { alternative meets all the SCADA and ITTS } \\
\text { requirements. This alternative supplies } \\
\text { high system reliability preferred by the } \\
\text { BPA. }\end{array}$ & \\
\hline $\begin{array}{l}\text { Maintenance Costs Costs are well below } \\
\text { the } 10 \% \text { threshold. }\end{array}$ & \\
\hline $\begin{array}{l}\text { System Design and Configuration. } \\
\text { Expansion is accomplished at any facility } \\
\text { that has two dedicated fiber circuits } \\
\text { available. No new facilities are required. }\end{array}$ & \\
\hline $\begin{array}{l}\text { Parts Availability. Parts and components } \\
\text { for this alternative are available from a } \\
\text { wide variety of vendors. }\end{array}$ & \\
\hline $\begin{array}{l}\text { Maintenance Policy. Meets all } \\
\text { maintenance policies and procedures. }\end{array}$ & \\
\hline
\end{tabular}


4.3.4.5 Alternative Costs. Costs for implementing this alternative are:

New Fiber Between 151KW Substation and 100K Node New Fiber Between ASHE Substation and 400 Area Node New Fiber Between 251W Substation and 200W Node SCADA equipment purchase and installation ITTS equipment purchase and installation

TOTAL
$=\$ 21,000$

$=\$ 219,000$

$=\$ 150,000$

$=\$ 105,000$

$=\$ 105,000$

$=\$ 600,000$

Cost avoidance to L.273 Project

$\$ 381,000$

Variance

$\$ 219,000$ 


\subsection{EVALUATION OF ALTERNATIVES}

\subsection{ANALYSIS OF COSTS}

A life cycle cost analysis was performed on the alternatives. the analysis computed the relative costs of the alternatives in terms of present dollars using a discount rate of 2.8 percent ${ }^{9}$. The details of this analysis are shown in Appendix $B$. Table $X$ provides a summary of the life cycle cost analysis. The evaluation of cost shows the Alternative $C$, Transfer to the Upgraded Telecommunications Backbone System, to be the most costeffective in terms of raw life cycle costs as well as present dollars

Table V - Cost Analysis Summary (in \$K)

\begin{tabular}{||l|r|r||}
\hline \multicolumn{1}{|c|}{ Options } & $\begin{array}{r}\text { Raw Life Cycle } \\
\text { Costs }\end{array}$ & Present Value Costs \\
\hline Do Nothing & 620.8 & 553.8 \\
\hline $\begin{array}{l}\text { Replace with another Microwave } \\
\text { System }\end{array}$ & 481.0 & 446.4 \\
\hline \begin{tabular}{l} 
Migrate to Fiber Optic Facilities \\
\hline
\end{tabular}
\end{tabular}

\subsection{EVALUATION OF NON-COST FACTORS}

The criteria areas previously defined in Paragraph 4.1 analyzed using a weighted rating under the factors safety, operational effectiveness, maintainability, and cultural. Table $X$ shows the summary analysis of non-cost factors. Detaited computations of the analysis are shown in Appendix A.

Table VI - Summary of Non-cost Factors

\begin{tabular}{|l|r|r|r|r||}
\hline \multicolumn{1}{|c|}{ Factor } & Weight & \multicolumn{1}{|c|}{$\begin{array}{c}\text { Option 1: Do } \\
\text { Nothing }\end{array}$} & $\begin{array}{c}\text { Option 2: Upgrade } \\
\text { the Microwave } \\
\text { System }\end{array}$ & $\begin{array}{c}\text { Option 3: Transfer } \\
\text { to Upgraded } \\
\text { Telecommunications } \\
\text { Backbone }\end{array}$ \\
\hline Safety & $40 \%$ & 1.10 & 1.80 & 4.00 \\
\hline $\begin{array}{l}\text { O p e r a t i o n a } \\
\text { Effectiveness }\end{array}$ & $25 \%$ & 1.37 & 2.15 & 2.43 \\
\hline Maintainability & $25 \%$ & 0.42 & 1.73 & 1.00 \\
\hline Cultural & $10 \%$ & 0.40 & 0.10 & \\
\hline Total & $100 \%$ & & & \\
\hline
\end{tabular}

9 Based on guidance from Office of Management and Budget Circular A-94. 


\subsection{CAPITAL ASSET MANAGEMENT PROCESS}

The preferred alternative - Transfer to the Upgraded Telecommunications Backbone System - was evaluated for prioritization using the Capital Asset Management Process (CAMP) rating system ${ }^{10}$. The details of the analysis are shown in Appendix $C$. Table $X$ shows a summary of the CAMP analysis.

\section{Table VII - Capital Asset Management Analysis}

\begin{tabular}{||c|c|l|r|r||}
\hline Ranking & Category & Key Subcategory & Assigned value & $\begin{array}{l}\text { W e i g h t e d } \\
\text { Points }\end{array}$ \\
\hline Highest & IV & Infrastructure & 60 & 60 \\
\hline 1 & I & Industrial safety & 50 & 2.25 \\
\hline 2 & II & Corrective measures & 50 & 2.25 \\
\hline 3 & III & Infrastructure & 20 & 0 \\
\hline
\end{tabular}

${ }^{10}$ DOE 4320.2A, Capital asset Management Process 


\subsection{REFERENCES}

Brown, R; Spectrum Reallocation Final Report, February 1995

Rowlett, T; DOE Memorandum; Subject: Potential Interference Alert, August 22, 1995

DOE, 1994a, Capital Asset Management Process, DOE 4320.2A

DOE, 1994b, Maintenance Management Program, DOE 4330.4B

DOE-BPA, 1994, Letter of Agreement, dated November 23, 1994, Subject: Hanford Fiber Optic Loop, Department of Energy, Richland Operations Office, Richland, Washington.

\subsection{BIBLIOGRAPHY}

Brown, R; Spectrum Reallocation Final Report, February 1995

Carney, T; WHC-SD-GN-TPLN-30006, Rev 0; Gable Mountain Equipment Removal Conceptual Plan

Poe, R; $\quad$ WHC-SD-L.196-ER-001, Rev O, Engineering Report Hanford Infrastructure Fiber Loop Project L-196

Poe, R; $\quad$ WHC-SD-L196-PMP-001, Rev O; Produced Program Management Plan Project Number L-196 - Hanford Infrastructure Fiber Loop

Rowlett, T; DOE Memorandum; Subject: Potential Interference Alert, August 22, 1995 


\begin{tabular}{|r|r|r|l|}
\hline \multicolumn{4}{|c|}{ Farinon Radio Maintenance Summary } \\
\hline & Yo. of failures & $\begin{array}{l}\text { Ave turn-around } \\
\text { for parts (days) }\end{array}$ & $\begin{array}{l}\text { Unrepairable } \\
\text { Conditions }\end{array}$ \\
\hline 1984 & 2 & 38 & 0 \\
\hline 1985 & 3 & 123 & 0 \\
\hline 1986 & 9 & 52 & 0 \\
\hline 1987 & 4 & 85 & 0 \\
\hline 1988 & 10 & 40 & 0 \\
\hline 1989 & 3 & 30 & 0 \\
\hline 1990 & 2 & 59 & 0 \\
\hline 1991 & 5 & 69 & 0 \\
\hline 1992 & 5 & 53 & 1 \\
\hline 1993 & 3 & 143 & 0 \\
\hline 1994 & 3 & 104 & 1 \\
\hline 1995 & 3 & 52 & 0 \\
\hline Average & 4 & 71 & \\
\hline
\end{tabular}




\section{Farinon System Failure Trend}

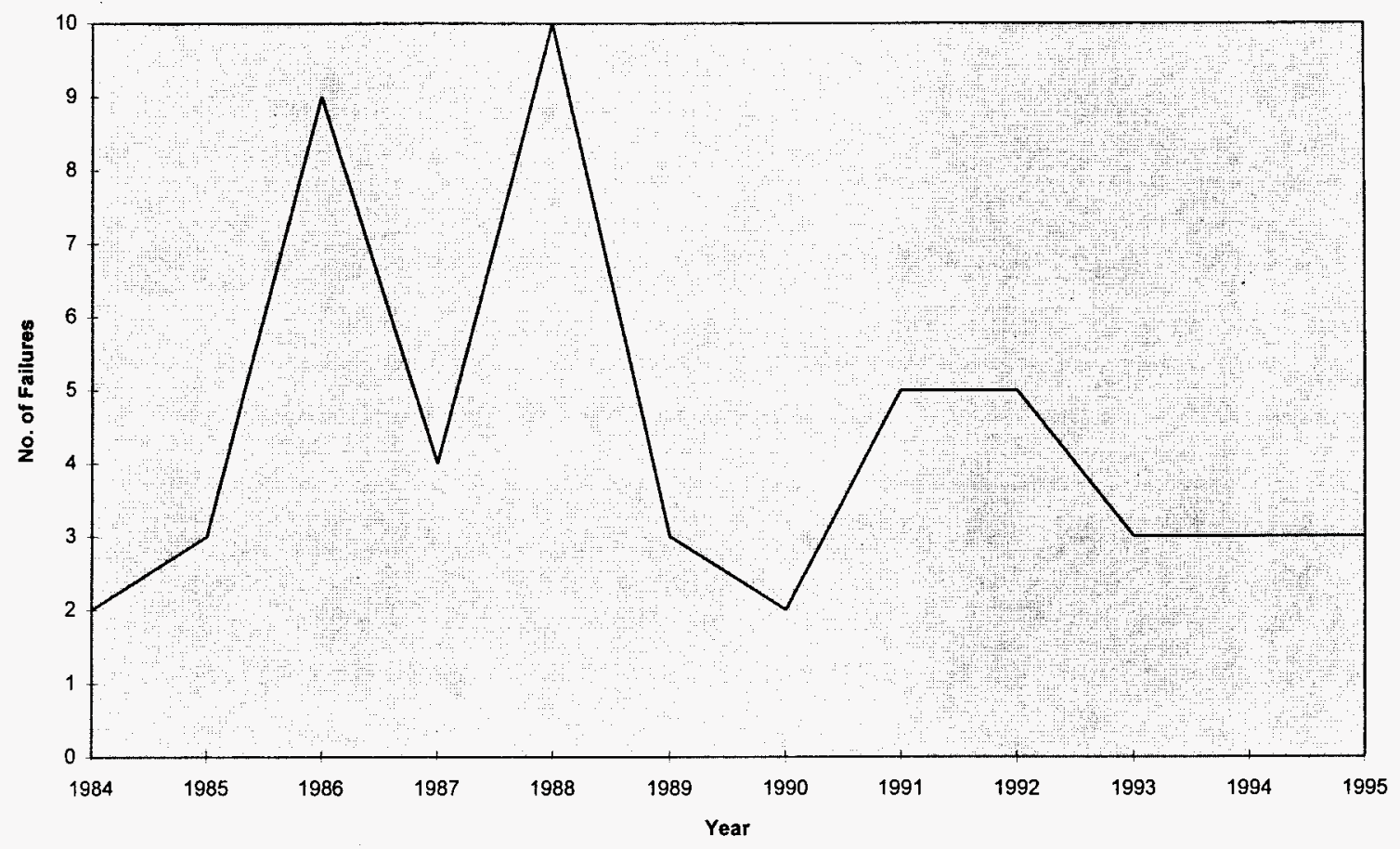


Farinon Parts Availability Data

\begin{tabular}{|l|l|l|c|c|c|}
\hline \multicolumn{1}{|c|}{ Part Description } & \multicolumn{1}{|c|}{$\begin{array}{c}\text { Supported } \\
\text { Component }\end{array}$} & \multicolumn{1}{c|}{ Part Number } & Repairable? & Repair Cost & $\begin{array}{c}\text { Replacement } \\
\text { Available? }\end{array}$ \\
\hline AGC Amplifier & Receiver Frame & SD-18886-001 & Yes & $\$ 395.00$ & Yes \\
\hline IF Amplifier & Receiver Frame & SD-18889-001 & Yes & $\$ 895.00$ & No \\
\hline Linear Amplifier & Transmit Frame & $076-100800-001$ & No & - & No \\
\hline Local Oscillator & Transmit Frame & SD-100779-003 & Yes & $\$ 495.00$ & No \\
\hline Local Oscillator & Transmit Frame & SD-100779-001 & Yes & $\$ 495.00$ & No \\
\hline Mixer/Pre-Amp & Receiver Frame & SD-102154-002 & Yes & $\$ 495.00$ & No \\
\hline Power Supply & Transmit Frame & SD-18305 & Yes & $\$ 2,501.00$ & \\
\hline Regulator & Transmit Frame & SD-18887-001 & Yes & $\$ 395.00$ & No \\
\hline Regulator & Transmit Frame & SD-18887-001 & Yes & $\$ 395.00$ & Yes \\
\hline Regulator & Receiver Frame & SD-18887-002 & Yes & $\$ 395.00$ & No \\
\hline RF Amplifier & Transmit Frame & SD-101482-002 & Yes & $\$ 495.00$ & No \\
\hline RF Amplifier & Receiver Frame & SD-18566-004 & Yes & $\$ 395.00$ & No \\
\hline Up Converter & Transmit Frame & $048-018612-007$ & Yes & $\$ 295.00$ & No \\
\hline
\end{tabular}




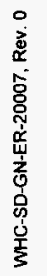

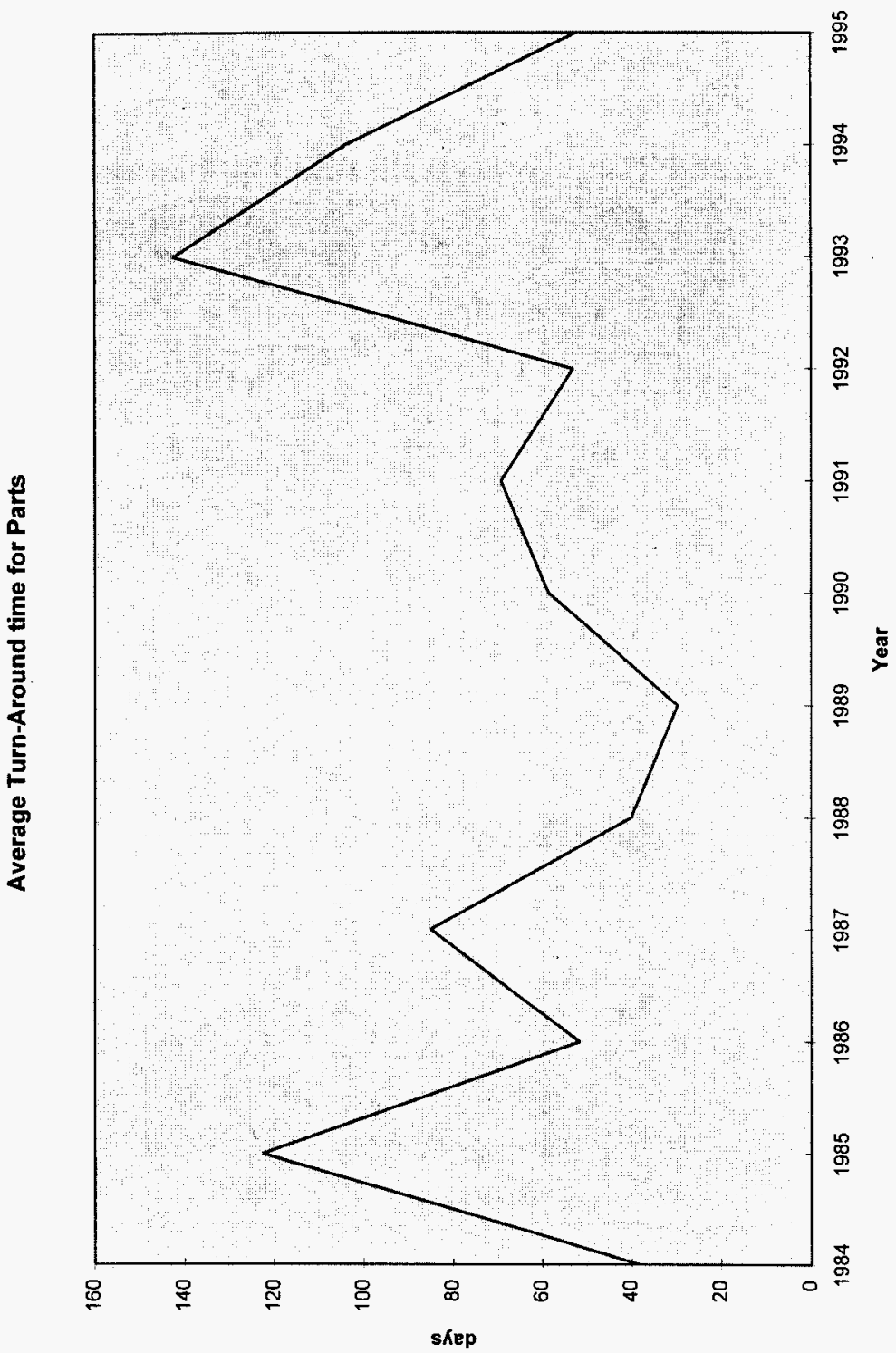

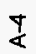




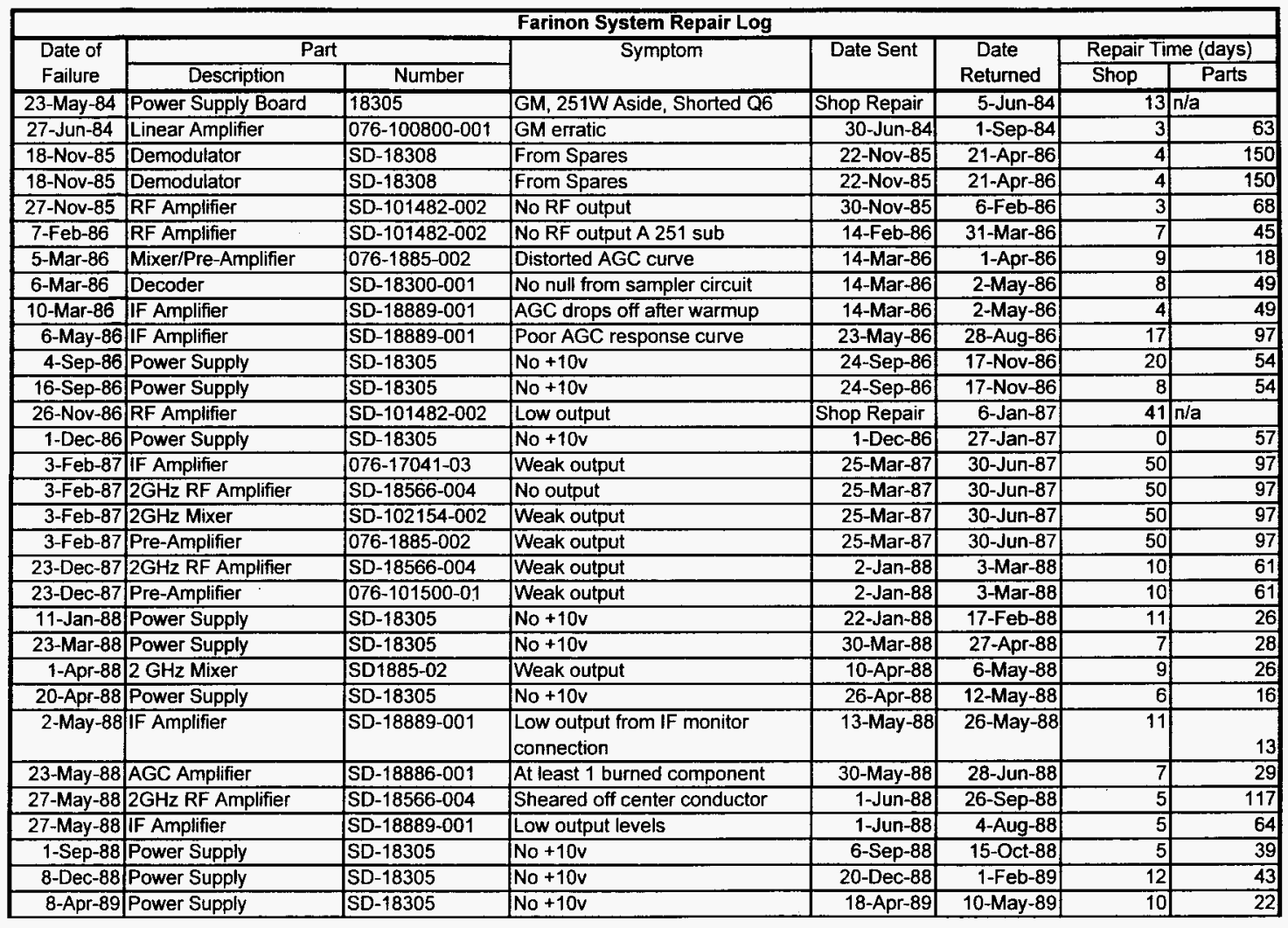




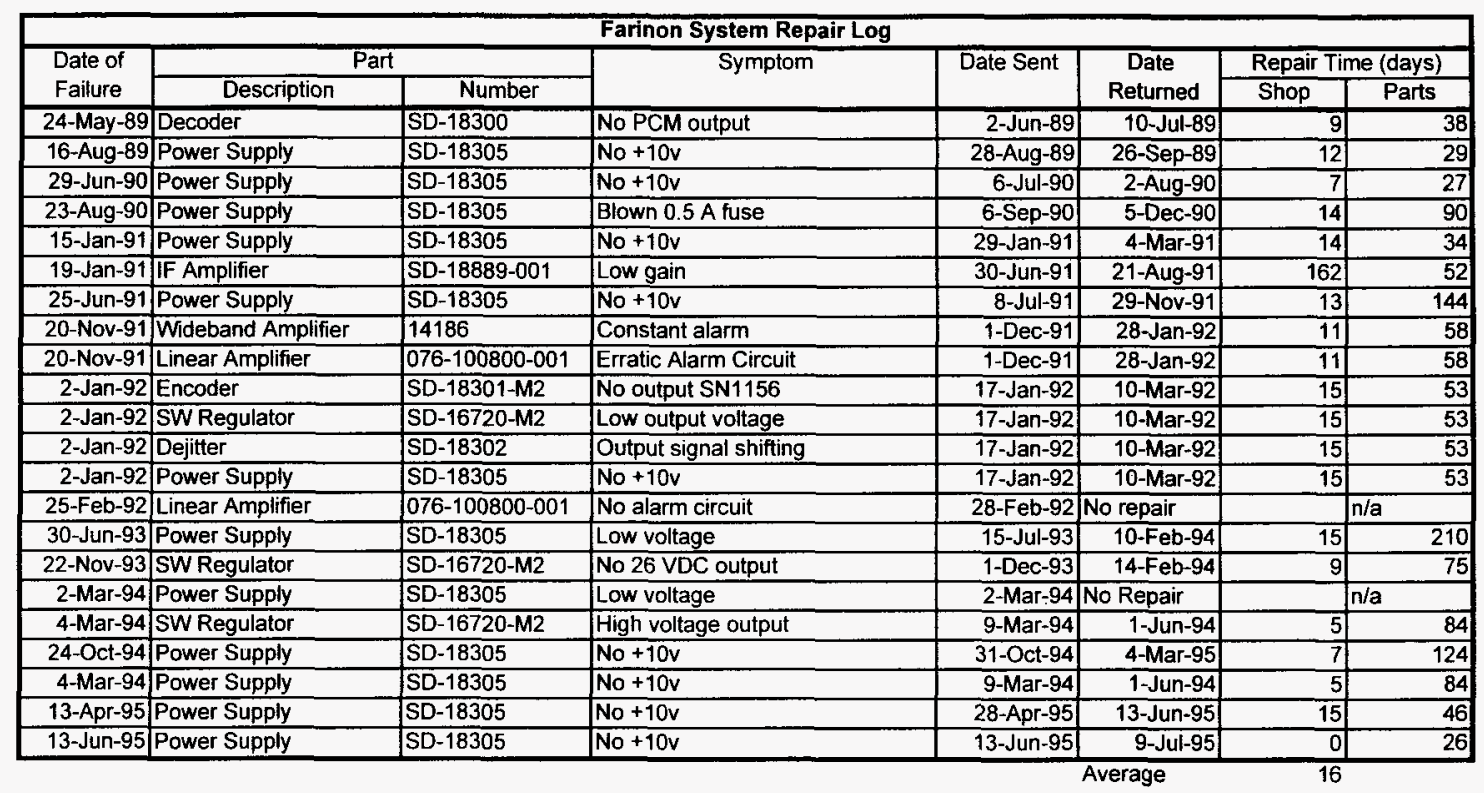




\begin{tabular}{|c|c|c|}
\hline \multicolumn{3}{|c|}{ Fiber Multiplex Equipment - Technical Capabilities for the Transfer Trip System } \\
\hline Technical Characteristic & Requirement & Remarks \\
\hline Equipment Configuration & Hot standby & $\begin{array}{l}\text { Common circuit card and power supply } \\
\text { redundancy }\end{array}$ \\
\hline Protection & ESD Hardened & $\begin{array}{l}\text { ESD will not affect Program, memory, or } \\
\text { hardware }\end{array}$ \\
\hline Optics & $1310 \mathrm{~nm}$ & \\
\hline Physical Interface & FC/PC connectors & \\
\hline Power Budget & $+3 \mathrm{~dB}$ & \\
\hline \multirow[t]{2}{*}{ Standards Criteria } & ANSI//EEE C37.90.1 & $\begin{array}{l}\text { Surge withstand capabilities and fast transient } \\
\text { testing requirements }\end{array}$ \\
\hline & ANSI/IEEE C37.90.2 & EMI/RFI Requirements \\
\hline \multirow[t]{4}{*}{ Channel Capacity } & 24 DSO & \\
\hline & 1 DS1 & Line raterogram \\
\hline & $1-19.2 \mathrm{KbpS}$ & RS-232 \\
\hline & $1-56 \mathrm{Kbps}$ & RS-442/449 \\
\hline Channel Signaling (Tone) & $\begin{array}{l}\text { High tone at } 2295+150 \mathrm{~Hz} \\
\text { low tone at } 1615+150 \mathrm{~Hz}\end{array}$ & \\
\hline VF Circuit Configuration & 4 W with $E / M$ & \\
\hline \multirow[t]{2}{*}{ VF Circuit Interface } & 600 Ohms balanced & \\
\hline & +7 to $-16 \mathrm{dBm}$ & \\
\hline VF Circuit Bandwidth & 0.3 to $3.4 \mathrm{KHz}$ & \\
\hline $\begin{array}{l}\text { VF Circuit Maximum Idle } \\
\text { Noise }\end{array}$ & $20 \mathrm{dBrnco}$ & \\
\hline Compatibility & D4 and ESF format & \\
\hline Power & -48 VDC & \\
\hline Temperature Range & $10-40^{\circ} \mathrm{C}\left(50-104^{\circ} \mathrm{F}\right)$ & \\
\hline Other Environmental & $\begin{array}{l}\text { Operate within } 305 \mathrm{~mm} \text { (1 foot) } \\
\text { of } 5 \mathrm{~W} \text { VHF radio }\end{array}$ & \\
\hline
\end{tabular}

Fiber Multiplex Equipment - Operational Requirements for the Transfer Trip System

\begin{tabular}{|l|l|l|}
\hline Characteristic & Requirement & Remarks \\
\hline General Routing & $\begin{array}{l}\text { Direct connect (dedicated) } \\
\text { circuit per each protected relay }\end{array}$ & All Circuits \\
\hline Entry to Substation & All-dielectric cables & Non-conductive sheath \\
\hline
\end{tabular}




\begin{tabular}{|l|l|l|}
\hline \multicolumn{2}{|c|}{ Fiber Multiplex Equipment - Administrative Requirements for the Transfer Trip System } \\
\hline Characteristic & Requirement & Remarks \\
\hline Design and Engineering & & \\
\hline Design Review & $\begin{array}{l}\text { BPA, ICF-KH EU, BCSR/US } \\
\text { WEST, DOE }\end{array}$ & \\
\hline Procurement & Turn-key & Ashe, 151KW, and 251 Substations \\
\hline Installation & Turn-key & Ashe, 151KW, and 251 Substations \\
\hline Testing & Turn-key & Ashe, 151KW, and 251 Substations \\
\hline System Start-up & Turn-key & Ashe, 151KW, and 251 Substations \\
\hline Operate and Maintain & Ashe & BPA \\
\cline { 2 - 3 } & $151 \mathrm{KW}, 251$ & CF KH EU \\
\hline Documentation and \\
spares
\end{tabular}


Summary Analysis of Weighted Ratings of Non-Cost Factors

\begin{tabular}{|l|r|r|r|r|}
\hline \multicolumn{1}{|c|}{ Factor } & Weight & Option 1: Do Nothing & $\begin{array}{r}\text { Option 2: Upgrade the } \\
\text { Microwave System }\end{array}$ & $\begin{array}{c}\text { Option 3: Transfer to } \\
\text { Upgraded } \\
\text { Telecommunications } \\
\text { Backbone }\end{array}$ \\
\hline Safety & $40 \%$ & 1.10 & 1.80 & 4.00 \\
\hline $\begin{array}{l}\text { Operational } \\
\text { Effectiveness }\end{array}$ & $25 \%$ & 1.37 & 2.15 & 2.43 \\
\hline Maintainability & $25 \%$ & 0.42 & 1.73 & 2.50 \\
\hline Cultural & $10 \%$ & 0.40 & 0.10 & 1.00 \\
\hline Total & $100 \%$ & & & \\
\hline
\end{tabular}

Non-Cost Factors Rating Sheet

\begin{tabular}{|l|r|c|c|c|}
\cline { 3 - 5 } \multicolumn{1}{c|}{} & Weight & Option 1: Do Nothing & $\begin{array}{c}\text { Option 2: Upgrade the } \\
\text { Microwave System }\end{array}$ & $\begin{array}{c}\text { Option 3: Transfer to } \\
\text { Upgraded } \\
\text { Telecommunications } \\
\text { Backbone }\end{array}$ \\
\hline General Safety & $10 \%$ & 3 & 7 & 10 \\
\hline Equipment Safety & $10 \%$ & 4 & 7 & 10 \\
\hline Personnel Safety & $20 \%$ & 2 & 2 & 10 \\
\hline Site operations and \\
services
\end{tabular}

Rating $1-10,1=$ worst, $10=$ Best 
Evaluation of Non-Cost Factors - Option 1: Do Nothing

\begin{tabular}{|l|r|r|r|}
\hline \multicolumn{4}{|c|}{ Category: Safety } \\
\hline Criteria & Weight & Raw Rating & Weighted Rating \\
\hline General Safety & $10 \%$ & 3 & 0.30 \\
\hline Equipment Safety & $10 \%$ & 4 & 0.40 \\
\hline Personnel Safety & $20 \%$ & 2 & 0.40 \\
\hline Total & $40 \%$ & 9 & 1.10 \\
\hline
\end{tabular}

\begin{tabular}{|l|r|r|r|}
\hline \multicolumn{4}{|c|}{ Category: Operational Effectiveness } \\
\hline Criteria & Weight & Raw Rating & Weighted Rating \\
\hline $\begin{array}{l}\text { Site operations and } \\
\text { services }\end{array}$ & $5 \%$ & 1 & 0.05 \\
\hline Frequency Availability & $4 \%$ & 1 & 0.04 \\
\hline SCADA Criteria & $7 \%$ & 8 & 0.56 \\
\hline ITS Criteria & $9 \%$ & 8 & 0.72 \\
\hline Total & $25 \%$ & 18 & 1.37 \\
\hline
\end{tabular}

\begin{tabular}{|l|r|r|r|}
\hline \multicolumn{4}{|c|}{ Category: Maintainability } \\
\hline Criteria & Weight & Raw Rating & Weighted Rating \\
\hline Maintenance Costs & $4 \%$ & 1 & 0.04 \\
\hline System Design & $3 \%$ & 4 & 0.12 \\
\hline Parts Availability & $10 \%$ & 1 & 0.10 \\
\hline Maintenance Policy & $8 \%$ & 2 & 0.16 \\
\hline Total & $25 \%$ & 2 & 0.42 \\
\hline
\end{tabular}

\begin{tabular}{|l|r|r|r|}
\hline \multicolumn{3}{|c|}{ Category: Cultural lssues } \\
\hline Criteria & Weight & Raw Rating & Weighted Rating \\
\hline $\begin{array}{l}\text { Gable Mountain Cultural } \\
\text { Issues }\end{array}$ & $10 \%$ & 4 & 0.40 \\
\hline Total & $10 \%$ & 4 & 0.4 \\
\hline
\end{tabular}


Evaluation of Non-Cost Factors - Option 2: Upgrade the Microwave System

\begin{tabular}{|l|r|r|r|}
\hline \multicolumn{4}{|c|}{ Category: Safety } \\
\hline Criteria & Weight & Raw Rating & Weighted Rating \\
\hline General Safety & $10 \%$ & 7 & 0.70 \\
\hline Equipment Safety & $10 \%$ & 7 & 0.70 \\
\hline Personnel Safety & $20 \%$ & 2 & 0.40 \\
\hline Total & $40 \%$ & 16 & 1.80 \\
\hline
\end{tabular}

\begin{tabular}{|l|r|r|r|}
\hline \multicolumn{3}{|c|}{ Category: Operational Effectiveness } \\
\hline Criteria & Weight & Raw Rating & Weighted Rating \\
\hline Site operations and & $5 \%$ & 8 & 0.40 \\
services & $4 \%$ & 6 & 0.24 \\
\hline Frequency Availability & $7 \%$ & 10 & 0.70 \\
\hline SCADA Criteria & $9 \%$ & 9 & 0.81 \\
\hline ITTS Criteria & $25 \%$ & 33 & 2.15 \\
\hline Total & & & \\
\hline
\end{tabular}

\begin{tabular}{|l|r|r|r|}
\hline \multicolumn{3}{|c|}{ Category: Maintainability } \\
\hline Criteria & Weight & Raw Rating & Weighted Rating \\
\hline Maintenance Costs & $4 \%$ & 6 & 0.24 \\
\hline System Design & $3 \%$ & 5 & 0.15 \\
\hline Parts Availability & $10 \%$ & 7 & 0.70 \\
\hline Maintenance Policy & $8 \%$ & 8 & 0.64 \\
\hline Total & $25 \%$ & 26 & 1.73 \\
\hline
\end{tabular}

Category: Cultural Issues

\begin{tabular}{|l|l|l|l|}
\hline Criteria & Weight & Raw Rating. & Weighted Rating \\
\hline Gable Mountain Cultural is & $10 \%$ & 1 & 0.10 \\
\hline Total & $10 \%$ & 1 & 0.10 \\
\hline
\end{tabular}


valuation of Non-Cost Factors - Option 3: Transfer to Upgraded Telecommunications Backbone

\begin{tabular}{|l|r|r|r|}
\hline \multicolumn{4}{|c|}{ Category: Safety } \\
\hline Criteria & & Raw Rating & Weighted Rating \\
\hline General Safety & $10 \%$ & 10 & 1.00 \\
\hline Equipment Safety & $10 \%$ & 10 & 1.00 \\
\hline Personnel Safety & $20 \%$ & 10 & 2.00 \\
\hline Total & $40 \%$ & 30 & 4.00 \\
\hline
\end{tabular}

\begin{tabular}{|l|r|r|r|}
\hline \multicolumn{4}{|c|}{ Category: Operational Effectiveness } \\
\hline Criteria & Weight & Raw Rating & Weighted Rating \\
\hline $\begin{array}{l}\text { Site operations and } \\
\text { services }\end{array}$ & $5 \%$ & 10 & 0.50 \\
\hline Frequency Availability & $4 \%$ & 10 & 0.40 \\
\hline SCADA Criteria & $7 \%$ & 9 & 0.63 \\
\hline ITTS Criteria & $9 \%$ & 10 & 0.90 \\
\hline Total & $25 \%$ & 39 & 2.43 \\
\hline
\end{tabular}

\begin{tabular}{|l|r|r|r|}
\hline \multicolumn{3}{|c|}{ Category: Maintainability } \\
\hline Criteria & Weight & Raw Rating & Weighted Rating \\
\hline Maintenance Costs & $4 \%$ & 10 & 0.40 \\
\hline System Design & $3 \%$ & 10 & 0.30 \\
\hline Parts Availability & $10 \%$ & 10 & 1.00 \\
\hline Maintenance Policy & $8 \%$ & 10 & 0.80 \\
\hline Total & $25 \%$ & 40 & 2.50 \\
\hline
\end{tabular}

\begin{tabular}{|l|r|r|r|}
\hline \multicolumn{4}{|c|}{ Category: Cultural Issues } \\
\hline Criteria & Weight & Raw Rating & Weighted Rating \\
\hline Gable Mountain Cultural & $10 \%$ & 10 & 1.00 \\
\hline Total & $10 \%$ & 10 & 1.00 \\
\hline
\end{tabular}




\section{Cost Analysis Summary (in \$K)}

\begin{tabular}{|l|r|r|}
\hline \multicolumn{1}{|c|}{ Options } & Raw Life Cycle Costs & Present Value Costs \\
\hline Do Nothing & 620.8 & 553.8 \\
\hline Replace with another Microwave System & 481.0 & 446.4 \\
\hline Migrate to Fiber Optic Facilities & 261.6 & 290.1 \\
\hline
\end{tabular}

Assumptions:

Based on 10-yr life cycle costs

Present Value computed at $2.8 \%$ discount rate (Current rate for OMB Cir A-94).

Discount Rate is based on OMB guidance for constant dollars and no inflationary projections.

Assumes a standard one-year warranty on purchase of new equipment.

Do nothing option assumes a $20 \%$ increase in maintenance costs on existing equipment.

Maintenance cost of new equipment estimated at $5 \%$ of replacement cost 
Capital Costs (One-time)

Replace Microwave (Freq Chg)

Equipment

Labor

Frequency Coordination

Raw Total

Recurring Costs (Annual)

Periodic Maintenance

Emergent Maintenance

Annual Total

Maintenance New Sys

Annual Total

Raw Life-Cycle Costs

Present Value Life Cycle Costs

\section{Option1 - Do Nothing (in \$K)}

211 Alloc 2002, Implement 2004

31.65

25

267.65

Escalation 20\%

$21.53 \mathrm{hrs} X 2$ techs $X \$ 59.75 / \mathrm{hr}$

$X 12$ trips $X 5$ Systems locations

9.8 (12 hrs $X 2$ techs)+(Average time in shop $\times 20 \%$ )

$\mathrm{X} \$ 59.75 / \mathrm{hr}$

31.3

+ Ave Cost of Part X Ave. events/yr.

10.5 Start 2005 (assumes 1 yr warranty)

10.6

620.8

553.8 
Option 2 - Replace the Collins with another Microwave System (in \$K)

Capital Costs (One-time)

Microwave

Frequency Changes

Transmitters

Frequency Coordination

Capital Total

Recurring Costs (Annual)

Maintenance

Service

Recurring Costs
211.0

105.0 Alloc FY 2002

25.0 Alloc FY 2002

341.0

Maintenance and service costs are based on a percentage of purchase value

Raw Life-Cycle Costs

Present Value Life Cycle Costs
481.0

446.4 


\section{Option 3 - Migrate from Microwave to Fiber Optic Facilities (in \$K)}

Capital Costs (One-time)

Install Cable \& Equipment

219

Other Costs

Engineering - Detail Design

20.1

Total

239.1

Recurring Costs

Maint on Mux

Other recurring Costs are covered under current organization headcount

Raw Life-Cycle Costs

Present Value Costs
261.6

290.1 


\begin{tabular}{|c|c|c|c|c|c|c|c|c|c|c|c|}
\hline \multicolumn{12}{|c|}{ Present Value Cost Analysis } \\
\hline Year & 0 & 1 & 2 & 3 & 4 & 5 & 6 & 7 & 8 & & |Total \\
\hline Option 1 & 31.3 & 36.6 & 42.7 & 49.8 & 58.1 & 301.0 & 8.9 & 8.7 & 8.5 & 8.2 & 553.8 \\
\hline Option 2 & 211 & 15.1 & 14.7 & 14.3 & 13.9 & 126.8 & 13.2 & 12.8 & 12.5 & 12.1 & 446.4 \\
\hline Option 3 & 270.4 & 2.4 & 2.4 & 2.3 & 2.2 & 2.2 & 2.1 & 2.1 & 2.0 & 1.9 & 290.1 \\
\hline
\end{tabular}

Discount Rate

$2.8 \%$

${ }^{1}$ Years $0-4$ Costs assume an increase in costs due to difficulties in maintenance support Rate of Increase $=$

$20 \%$

Process for computing life cycle costs in terms of present dollars:

The following formula is used to determine the value of a dollar spent in the future interms of its present value (PV):

$$
P V=\frac{P}{(1+i)^{n}} \quad \begin{aligned}
& \text { Where: } \quad \begin{array}{l}
P \\
\text { P }
\end{array} \quad \text { The amount of dollars allocated (principal). } \\
& \mathrm{n}=\text { The discount (or interest rate). } \\
& n=\text { the number of years in the future that the dollars will be allocated }
\end{aligned}
$$

This formula permits a more quantitative analysis of costs in the decision-making process.

It is based on the concept that the dollars would be available to gain interest until they are allocated. 


\section{Years to Payback Computations}

\begin{tabular}{|c|c|c|c|c|c|c|c|c|c|c|}
\hline \multicolumn{11}{|c|}{ Payback Rate - Option 2: Replace the Microwave System } \\
\hline Year & 0 & 1 & 2 & 3 & 4 & 5 & 6 & 7 & 8 & 9 \\
\hline Benefit & -179.7 & -158.3 & -130.3 & -94.8 & -50.6 & 123.6 & 119.4 & 115.3 & 111.3 & 107.4 \\
\hline
\end{tabular}

Payback year: 5

\begin{tabular}{|c|c|c|c|c|c|c|c|c|c|c|}
\hline \multicolumn{11}{|c|}{ Payback Rate - Option 3: Transfer to the Upgraded Telecommunications Backbone } \\
\hline Year & 0 & 1 & 2 & 3 & 4 & 5 & 6 & 7 & 8 & 9 \\
\hline
\end{tabular}

Payback year:

5

Payback rate computed cost of maintenance of the existing system as a benefit since it would no longer be a recurring cost Computation: Initial capital plus sum of annual expenses less cost of maintaining existing systems 


\section{CAPITAL ASSET MANAGEMENT PROCESS (CAMP) ANALYSIS}

\section{Project:}

Transfer to the Upgraded Telecommunications Backbone

\begin{tabular}{|l|l|}
\hline Project Lead/Manager & Robin C. Poe \\
\hline
\end{tabular}

Instructions: 1. Assign value ratings for the subcategories on sheets 2-5.

2. Proceed to sheet 6 for evaluation of ratings.

3. Complete Summary calculations below.

\section{SUMMARY CALCULATIONS}

\begin{tabular}{|c|c|l|r|r|}
\hline Ranking & Category & Key Subcategory & Assigned value & Weighted Points \\
\hline Highest & IV & Infrastructure & 60 & 60 \\
\hline 1 & I & Industrial safely & 50 & 2.25 \\
\hline 2 & II & Corrective measures & 50 & 2.25 \\
\hline 3 & III & Infrastructure & 20 & 0 \\
\hline
\end{tabular}

Category: Enter Roman numeral I, II, III, or IV from major category designation

Key

Subcategory From Sheet 6

Assigned

value From Sheet 6

\section{Probability and Frequency Terms}

\begin{tabular}{|l|l|}
\hline Standardized Term & Probability \\
\hline Essentially Impossible & $<1: 10^{8}$ \\
\hline Extremely Unlikely & $1: 10^{8}-1: 10^{6}$ \\
\hline Unlikely & $1: 10^{6}-1: 1000$ \\
\hline Slightly likely & $1: 1000-1: 100$ \\
\hline Possible & $1: 100-1: 10$ \\
\hline Moderately Likely & $1: 10-1: 2.5$ \\
\hline Likely & $1: 2.5-1: 1.4$ \\
\hline Highly Likely & $1: 1.4-1: 1$ \\
\hline
\end{tabular}

C-1 


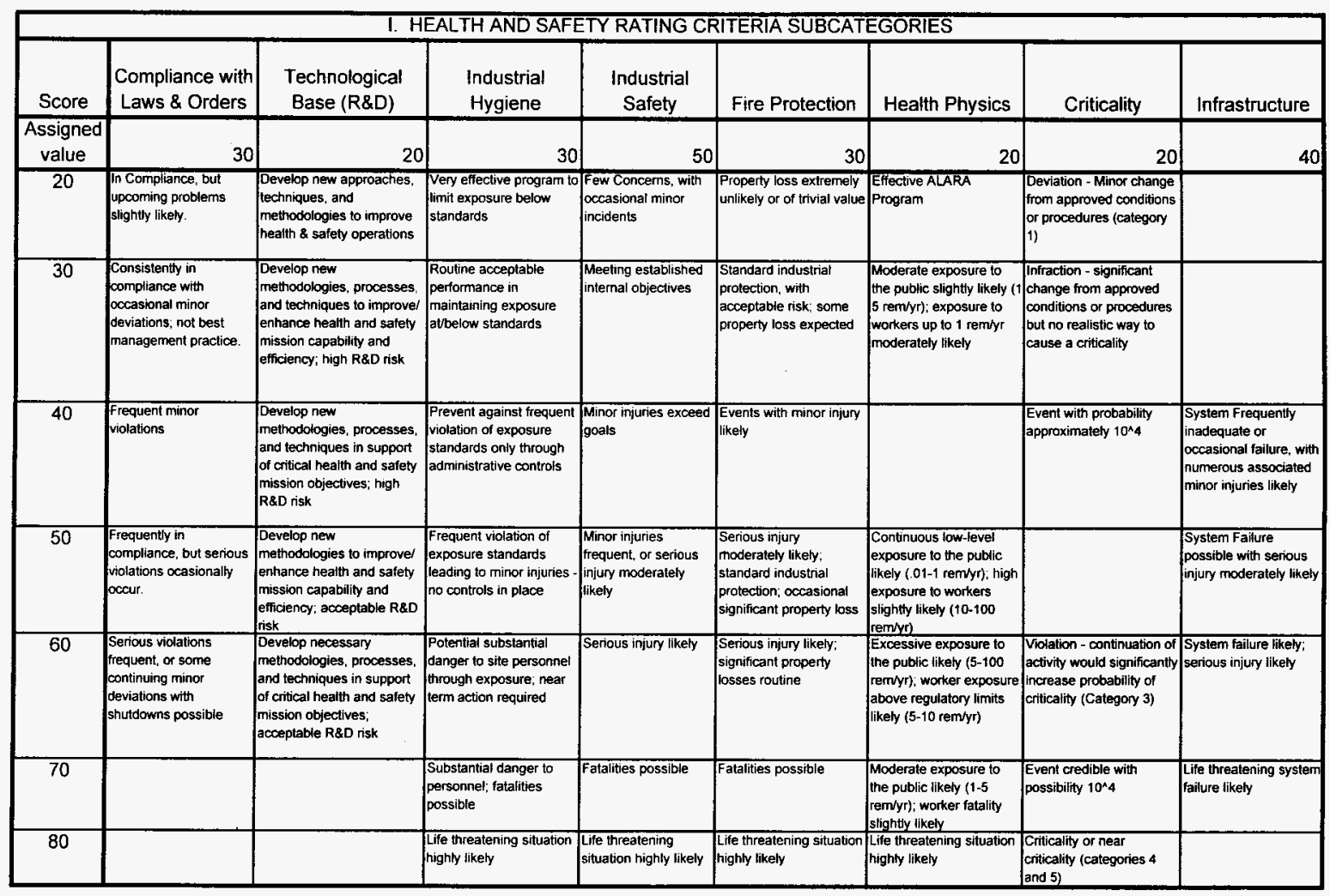




\begin{tabular}{|c|c|c|c|c|c|c|c|c|c|}
\hline \multicolumn{10}{|c|}{ II. ENVIRONMENTAL AND WASTE MANAGEMENT RATING CRITERIA SUBCATEGORIES } \\
\hline Score & $\begin{array}{l}\text { Compliance } \\
\text { with Laws } \\
\text { and Orders }\end{array}$ & $\begin{array}{l}\text { Technological } \\
\text { Base (R\&D) }\end{array}$ & $\begin{array}{c}\text { Liquid and } \\
\text { Hazardous } \\
\text { Waste }\end{array}$ & $\begin{array}{c}\text { Solid and } \\
\text { Hazardous } \\
\text { Waste }\end{array}$ & $\begin{array}{l}\text { Airborne } \\
\text { Pollutants }\end{array}$ & $\begin{array}{c}\text { Waste } \\
\text { Minimization }\end{array}$ & $\begin{array}{c}\text { Environmental } \\
\text { Restoration }\end{array}$ & $\begin{array}{c}\text { Corrective } \\
\text { Actions }\end{array}$ & Infrastructure \\
\hline $\begin{array}{c}\text { Assigned } \\
\text { value }\end{array}$ & 20 & 20 & 20 & 20 & 20 & 20 & 30 & 50 & 20 \\
\hline 20 & & $\begin{array}{l}\text { Develoo new } \\
\text { approaches, techniques, } \\
\text { and methodologies to } \\
\text { improve environmental \& } \\
\text { waste management } \\
\text { operations }\end{array}$ & & & $\begin{array}{l}\text { Consistently meets } \\
\text { requirements }\end{array}$ & $\begin{array}{l}\text { Process generates } \\
\text { relatively little waste }\end{array}$ & $\begin{array}{l}\text { Decontaminating and } \\
\text { decommissioning } \\
\text { (D\&D) at sites with no } \\
\text { present imperatives }\end{array}$ & & \\
\hline 30 & $\begin{array}{l}\text { Consistently in } \\
\text { compliance with } \\
\text { occasional minor } \\
\text { deviations; not best } \\
\text { management } \\
\text { practice. }\end{array}$ & $\begin{array}{l}\text { Develop new } \\
\text { methodologies. } \\
\text { processes, and } \\
\text { techniques to improvel } \\
\text { enhance environmental } \\
\text { \& waste management } \\
\text { mission capability and } \\
\text { efficiency; high R\&D risk }\end{array}$ & $\begin{array}{l}\text { Occasional } \\
\text { discharge exceeding } \\
\text { material goals }\end{array}$ & & $\begin{array}{l}\text { Emissions currently } \\
\text { within permitted } \\
\text { levels, but hard to } \\
\text { maintain }\end{array}$ & \begin{tabular}{|l|} 
Process generates \\
more waste then an \\
efficient process
\end{tabular} & $\begin{array}{l}\text { Remedial action D\&D } \\
\text { needed to reduce risk, } \\
\text { promote compliance, } \\
\text { or maintain mission } \\
\text { continuity }\end{array}$ & & \\
\hline 40 & $\begin{array}{l}\text { Occasional or } \\
\text { frequent minor } \\
\text { violations }\end{array}$ & $\begin{array}{l}\text { Develop new } \\
\text { methodologies, } \\
\text { processes, and } \\
\text { techniques in support of } \\
\text { critical environmental \& } \\
\text { wasle management } \\
\text { mission objectives; high } \\
\text { R\&D risk }\end{array}$ & \begin{tabular}{|l|}
$\begin{array}{l}\text { Occasional violation } \\
\text { of discharge limit }\end{array}$ \\
\end{tabular} & $\begin{array}{l}\text { Occasional } \\
\text { inadequacy of } \\
\text { permitted storage/ } \\
\text { handling/ transport' } \\
\text { packaging/ disposai } \\
\text { capacity }\end{array}$ & \begin{tabular}{|l|} 
Emissions \\
occasionally exceed \\
permitted ievels by a \\
small amount
\end{tabular} & $\begin{array}{l}\text { Process generates } \\
\text { excessive waste }\end{array}$ & & & $\begin{array}{l}\text { System Frequentty } \\
\text { inadequate or occasional } \\
\text { failure, with numerous } \\
\text { occasional } \\
\text { environmental permit } \\
\text { violations }\end{array}$ \\
\hline 50 & $\begin{array}{l}\text { Frequently in } \\
\text { compliance, but } \\
\text { serious violations } \\
\text { occasionally occur. }\end{array}$ & $\begin{array}{l}\text { Develop new } \\
\text { methodologies to } \\
\text { improve/ enhance } \\
\text { environmental } 8 \text { waste } \\
\text { management mission } \\
\text { capability and efficiency } \\
\text { acceptable R\&D risk }\end{array}$ & $\begin{array}{l}\text { Many of immediate } \\
\text { violations; lack of } \\
\text { adequate storage/ } \\
\text { treatment/ handling/ } \\
\text { transport/ packaging } \\
\text { facilities }\end{array}$ & $\begin{array}{l}\text { System capacity } \\
\text { frequently inadequate }\end{array}$ & \begin{tabular}{|l|} 
Ernissions \\
occasionally exceed \\
permitted levels by a \\
large amount
\end{tabular} & $\begin{array}{l}\text { Process generates } \\
\text { waste that exceeds } \\
\text { regulatory limits }\end{array}$ & $\begin{array}{l}\text { Remedial actions/ D\&D } \\
\text { required by in-force } \\
\text { agreement }\end{array}$ & $\begin{array}{l}\text { Out-of-compliance } \\
\text { with requirements, } \\
\text { but no signed } \\
\text { agreement }\end{array}$ & $\begin{array}{l}\text { System Faiture possible } \\
\text { associated with } \\
\text { occasional serious } \\
\text { environmental viotations } \\
\text { or frequent excessive } \\
\text { waste generation }\end{array}$ \\
\hline
\end{tabular}




\begin{tabular}{|c|c|c|c|c|c|c|c|c|c|}
\hline Score & $\begin{array}{l}\text { Compliance } \\
\text { with Laws } \\
\text { and Orders }\end{array}$ & $\begin{array}{c}\text { Technological } \\
\text { Base (R\&D) }\end{array}$ & $\begin{array}{l}\text { NMENTAL AND } \\
\begin{array}{c}\text { Liquid and } \\
\text { Hazardous } \\
\text { Waste }\end{array}\end{array}$ & $\begin{array}{c}\text { WASTE MAN } \\
\begin{array}{c}\text { Solid and } \\
\text { Hazardous } \\
\text { Waste }\end{array}\end{array}$ & $\begin{array}{l}\text { Airborne } \\
\text { Pollutants }\end{array}$ & $\begin{array}{c}\text { Waste } \\
\text { Minimization }\end{array}$ & $\begin{array}{c}\text { Environmental } \\
\text { Restoration }\end{array}$ & $\begin{array}{c}\text { Corrective } \\
\text { Actions }\end{array}$ & Infrastructure \\
\hline $\begin{array}{l}\text { Assigned } \\
\text { value }\end{array}$ & 20 & 20 & 20 & 20 & 20 & 20 & 30 & 50 & 20 \\
\hline 60 & $\begin{array}{l}\text { Serious violations } \\
\text { frequent, violation } \\
\text { of law with potential } \\
\text { serious civil or } \\
\text { criminal problems }\end{array}$ & $\begin{array}{l}\text { Develop necessary } \\
\text { methodologies, } \\
\text { processes, and } \\
\text { techniques in support of } \\
\text { critical environmental \& } \\
\text { waste management } \\
\text { mission objectives; } \\
\text { acceptable R\&D risk }\end{array}$ & $\begin{array}{l}\text { Offsite discharge } \\
\text { extremely high on } \\
\text { occasion (not life } \\
\text { threatening) }\end{array}$ & $\begin{array}{l}\text { System inadequate } \\
\text { with likety serious } \\
\text { environmental } \\
\text { impact; shutofown } \\
\text { possible }\end{array}$ & $\begin{array}{l}\text { Emissions extremely } \\
\text { high on occasion } \\
\text { (but not life } \\
\text { threatening) }\end{array}$ & $\begin{array}{l}\text { Process generates } \\
\text { waste such that } \\
\text { severe } \\
\text { environmental impact } \\
\text { is likely }\end{array}$ & \begin{tabular}{|l|} 
Actions required as \\
part of a signed \\
interagency agreement
\end{tabular} & $\begin{array}{l}\text { Actions required as } \\
\text { part of a signed } \\
\text { interagency } \\
\text { agreement }\end{array}$ & $\begin{array}{l}\text { System failure likely with } \\
\text { associated frequent } \\
\text { serious violations of } \\
\text { environmental } \\
\text { regulations or law }\end{array}$ \\
\hline 70 & & & $\begin{array}{l}\text { Offsite discharge } \\
\text { extremely high on } \\
\text { occasion (life } \\
\text { threatening possible) }\end{array}$ & $\begin{array}{l}\text { System inadequate } \\
\text { with highly likely } \\
\text { serious } \\
\text { environmental } \\
\text { impact; near term } \\
\text { significant risks } \\
\end{array}$ & $\begin{array}{l}\text { Emissions extremely } \\
\text { high on occasion (life } \\
\text { threatening possible) }\end{array}$ & & $\begin{array}{l}\text { Remedial actions/ D\&D } \\
\text { required to protect from } \\
\text { near-term significant } \\
\text { risks }\end{array}$ & $\begin{array}{l}\text { Actions needed } \\
\text { within } 1 \text { year to } \\
\text { prevent significant } \\
\text { risk }\end{array}$ & $\begin{array}{l}\text { System failure highly } \\
\text { likely, expected to result } \\
\text { in severe environmental } \\
\text { impact or extremely high } \\
\text { emissions }\end{array}$ \\
\hline 80 & & & & & & & & & \\
\hline
\end{tabular}




\begin{tabular}{|c|c|c|c|c|c|c|c|c|}
\hline \multicolumn{9}{|c|}{ III. SAFEGUARDS AND SECURITY RATING CRITERIA SUBCATEGORIES* } \\
\hline Score & $\begin{array}{c}\text { Compliance with } \\
\text { Orders, } \\
\text { Regulations, } \\
\text { Policies, MSSA }\end{array}$ & $\begin{array}{c}\text { Technological Base } \\
\text { (R\&D) }\end{array}$ & SNM Accountability & Protection of SNM & $\begin{array}{c}\text { Protection of } \\
\text { Class. Info., } \\
\text { Technology, and } \\
\text { Parts (Non-SNM) }\end{array}$ & $\begin{array}{l}\text { Protection of } \\
\text { Property from } \\
\text { Theft \& Loss } \\
\text { (Non-SNM, } \\
\text { Unclassified) }\end{array}$ & $\begin{array}{l}\text { Protection from } \\
\text { Hostile Action }\end{array}$ & Infrastructure \\
\hline $\begin{array}{c}\text { Assigned } \\
\text { value }\end{array}$ & 20 & 20 & 20 & 20 & 20 & 20 & 20 & 20 \\
\hline 20 & $\begin{array}{l}\text { Consistently in } \\
\text { compliance, with some } \\
\text { minor deviations }\end{array}$ & $\begin{array}{l}\text { Develop new approaches, } \\
\text { techniques, and } \\
\text { methodologies to improve } \\
\text { safeguards \& security } \\
\text { operations }\end{array}$ & $\begin{array}{l}\text { Consistently meets } \\
\text { standards }\end{array}$ & $\begin{array}{l}\text { Very secure - only remote, } \\
\text { unlikely scenarios could } \\
\text { succeed }\end{array}$ & & $\begin{array}{l}\text { Some small losses } \\
\text { expected }\end{array}$ & & \\
\hline 30 & $\begin{array}{l}\text { Routinely in compliance } \\
\text { with occasional minor } \\
\text { deviations; not best } \\
\text { management practice. }\end{array}$ & $\begin{array}{l}\text { Develop new methodologies, } \\
\text { processes, and techniques to } \\
\text { improvel enhance safeguards } \\
\text { \& secunity mission capability } \\
\text { and efficiency; high R\&D risk }\end{array}$ & $\begin{array}{l}\text { Frequent or minor } \\
\text { problems, but } \\
\text { compensatory measures } \\
\text { available }\end{array}$ & $\begin{array}{l}\text { Theft or diversion } \\
\text { possibilities acceptably } \\
\text { countered }\end{array}$ & $\begin{array}{l}\text { Theft or tiversion } \\
\text { possibilities normally } \\
\text { countered }\end{array}$ & $\begin{array}{l}\text { Standard industrial } \\
\text { protection }\end{array}$ & $\begin{array}{l}\text { Safe and secure; } \\
\text { normal concerns }\end{array}$ & \\
\hline 40 & $\begin{array}{l}\text { Frequent in compliance, } \\
\text { but serious violations } \\
\text { occasionally occur for } \\
\text { classified information. } \\
\text { lechnology, and parts }\end{array}$ & $\begin{array}{l}\text { Develop new methodologies, } \\
\text { processes, and techniques in } \\
\text { support of critical safeguards } \\
\text { \& security mission objectives: } \\
\text { high R\&D risk }\end{array}$ & \begin{tabular}{|l|} 
Accountability difficult \\
within reasonable \\
reasonable response time, \\
but resolution moderately \\
likely
\end{tabular} & & & \begin{tabular}{|l|} 
Occasional \\
significant loss; \\
frequent minor toss
\end{tabular} & & $\begin{array}{l}\text { System frequently } \\
\text { inadequate or } \\
\text { occasional failure, with } \\
\text { associated minor } \\
\text { safeguards/ security } \\
\text { problems }\end{array}$ \\
\hline 50 & $\begin{array}{l}\text { Serious violations } \\
\text { frequent for classified } \\
\text { information, technology, } \\
\text { and parts }\end{array}$ & \begin{tabular}{l|} 
Develop new methodologies \\
to improve/ enhance \\
safeguards \& security mission \\
capability and efficiency: \\
acceptable R\&D risk
\end{tabular} & \begin{tabular}{|l|} 
Serious problems; \\
accountability uncertain \\
within reasonable response \\
time
\end{tabular} & $\begin{array}{l}\text { Theft or diversion } \\
\text { possibilities that evade } \\
\text { initial detection systems }\end{array}$ & & $\begin{array}{l}\text { Occasional major } \\
\text { loss }\end{array}$ & $\begin{array}{l}\text { Cannot reasonably } \\
\text { assure protection; } \\
\text { serious injury possible }\end{array}$ & $\begin{array}{l}\text { System failure possible } \\
\text { with occasional serious } \\
\text { security violations }\end{array}$ \\
\hline 60 & $\begin{array}{l}\text { Frequently in } \\
\text { compliance, but SNM } \\
\text { violations occasionally } \\
\text { occur. }\end{array}$ & \begin{tabular}{|l|} 
Develop necessaly \\
methodologies, processes, \\
and techniques in support of \\
critical safeguards \& security \\
mission objectives; \\
acceptable R\&D risk
\end{tabular} & Numerous SNM violations & $\begin{array}{l}\text { Cannot reasonably assure } \\
\text { protection }\end{array}$ & $\begin{array}{l}\text { Loss of NSI-classified } \\
\text { information, } \\
\text { technology, or parts is } \\
\text { likely (interntional or } \\
\text { unintentional) }\end{array}$ & & $\begin{array}{l}\text { Cannot reasonably } \\
\text { assure protection; } \\
\text { serious injury likely }\end{array}$ & $\begin{array}{l}\text { System failure likely with } \\
\text { associated serious } \\
\text { violations or inability to } \\
\text { reasonably assure SNM } \\
\text { protection }\end{array}$ \\
\hline 70 & $\begin{array}{l}\text { Many serious violations } \\
\text { for classified } \\
\text { information, technology, } \\
\text { and parts; many SNM } \\
\text { violations; pervasive } \\
\text { lack of compliance with } \\
\text { SNM regulations }\end{array}$ & & & $\begin{array}{l}\text { Reasonable scenarios } \\
\text { likely; deviations or theft } \\
\text { pathways apparent }\end{array}$ & & & $\begin{array}{l}\text { Terrorist attack or } \\
\text { hostage situation likely } \\
\text { with fatalities possible }\end{array}$ & $\begin{array}{l}\text { System failure likely with } \\
\text { numerous SNM } \\
\text { viofations or deviations/ } \\
\text { theft pathways }\end{array}$ \\
\hline
\end{tabular}




\begin{tabular}{|c|c|c|c|c|c|c|c|c|}
\hline \multicolumn{9}{|c|}{ III. SAFEGUARDS AND SECURITY RATING CRITERIA SUBCATEGORIES* } \\
\hline Score & $\begin{array}{c}\text { Compliance with } \\
\text { Orders, } \\
\text { Regulations, } \\
\text { Policies, MSSA }\end{array}$ & $\begin{array}{c}\text { Technological Base } \\
\text { (R\&D) }\end{array}$ & SNM Accountability & Protection of SNM & $\begin{array}{c}\text { Protection of } \\
\text { Class. Info., } \\
\text { Technology, and } \\
\text { Parts (Non-SNM) }\end{array}$ & \begin{tabular}{|c|} 
Protection of \\
Property from \\
Theft \& Loss \\
(Non-SNM. \\
Unclassified)
\end{tabular} & $\begin{array}{l}\text { Protection from } \\
\text { Hostile Action }\end{array}$ & Infrastructure \\
\hline $\begin{array}{l}\text { Assigned } \\
\text { value }\end{array}$ & 20 & 20 & 20 & 20 & 20 & 20 & 20 & 20 \\
\hline 80 & \begin{tabular}{|l|} 
Extreme threat to SNM \\
or personnel (highty \\
likely)
\end{tabular} & & & & & & & \\
\hline
\end{tabular}

* ADC should review this sheet prior to release if any rating greater than 30 


\begin{tabular}{|c|c|c|c|c|c|c|c|}
\hline \multicolumn{8}{|c|}{ IV. MISSION AND INVESTMENT RATING CRITERIA SUBCATEGORIES } \\
\hline Score & $\begin{array}{c}\text { Compliance with } \\
\text { Orders, Initiatives } \\
\text { and Directives }\end{array}$ & $\begin{array}{l}\text { Business } \\
\text { Benefits }\end{array}$ & $\begin{array}{c}\text { Technological Base } \\
\text { (R\&D) }\end{array}$ & \begin{tabular}{|c|} 
Mission \\
Capability, \\
Capacity, and \\
Quality
\end{tabular} & Asset Condition & Infrastructure & $\begin{array}{c}\text { National Business } \\
\text { Strategies } / \\
\text { Partnerships }\end{array}$ \\
\hline $\begin{array}{l}\text { Assigned } \\
\text { value }\end{array}$ & 30 & 50 & 20 & 50 & 40 & 60 & 20 \\
\hline 20 & $\begin{array}{l}\text { In Compliance, but } \\
\text { upcoming problems } \\
\text { slightly likely. }\end{array}$ & & $\begin{array}{l}\text { Develop new approaches, } \\
\text { techniques, and methodologies } \\
\text { to improve operations }\end{array}$ & $\begin{array}{l}\text { Adequate to meet } \\
\text { mission requirements }\end{array}$ & $\begin{array}{l}\text { Good-performs to original } \\
\text { specs with routine } \\
\text { preventive maintenance }\end{array}$ & - & $\begin{array}{l}\text { High likelihood of moderate } \\
\text { growth over long-term in direct } \\
\text { jobs and economy; DOE } \\
\text { involvement require due to } \\
\text { technotogy hurdles }\end{array}$ \\
\hline 30 & $\begin{array}{l}\text { Consistently in } \\
\text { compliance with } \\
\text { occasional minor } \\
\text { deviations; not best } \\
\text { management practice. }\end{array}$ & & $\begin{array}{l}\text { Develop new methodologies, } \\
\text { processes, and techniques to } \\
\text { improve/ enhance mission } \\
\text { capability and efficiency; high } \\
\text { R\&D risk }\end{array}$ & $\begin{array}{l}\text { Adequate to meet } \\
\text { mission requirements, } \\
\text { but improvements } \\
\text { warranted }\end{array}$ & $\begin{array}{l}\text { Adequate - but cannot } \\
\text { perform to all originat } \\
\text { spers; some corrective } \\
\text { maintenance required }\end{array}$ & & $\begin{array}{l}\text { High likelihood of moderate } \\
\text { growth over near-term or large } \\
\text { growth over long-term in direct } \\
\text { jobs and economy, DOE } \\
\text { involvement require due to } \\
\text { technology hurdles }\end{array}$ \\
\hline 40 & Frequent minor violations & $\begin{array}{l}\text { Project payback 8-10 } \\
\text { years for projects with } \\
\text { continuing need }\end{array}$ & $\begin{array}{l}\text { Develop new methodologies } \\
\text { processes, and techniques in } \\
\text { support of critical mission } \\
\text { objectives, high R\&D risk }\end{array}$ & $\begin{array}{l}\text { Adequate to meet } \\
\text { mission requirements: } \\
\text { probierns likgly }\end{array}$ & $\begin{array}{l}\text { Fair - occasional } \\
\text { substandard operation; } \\
\text { extensive corrective } \\
\text { maintenance }\end{array}$ & $\begin{array}{l}\text { System Frequenty inadequate or } \\
\text { occasional failure, with } \\
\text { associated frequent minor impact } \\
\text { on operation/mission }\end{array}$ & $\begin{array}{l}\text { High likelihood of moderate } \\
\text { growth over near-term in direct } \\
\text { djobs and economy; DOE } \\
\text { involvement require due to } \\
\text { technology hurdles }\end{array}$ \\
\hline 50 & $\begin{array}{l}\text { Frequently in compliance, } \\
\text { but serious viofations } \\
\text { occasionally occur. }\end{array}$ & $\begin{array}{l}\text { Project payback 4-7 } \\
\text { years for projects with } \\
\text { continuing need }\end{array}$ & $\begin{array}{l}\text { Develop new methodologies to } \\
\text { improve/ enhance mission } \\
\text { capability and efficiency: } \\
\text { acceptable R\&D risk }\end{array}$ & $\begin{array}{l}\text { Moderately likely not to } \\
\text { meet mission } \\
\text { requirements }\end{array}$ & \begin{tabular}{|l|} 
Poor - consistent \\
substandard performance
\end{tabular} & $\begin{array}{l}\text { System Failure possible, with } \\
\text { occasional inability to meet some } \\
\text { significant mission requirements }\end{array}$ & \\
\hline 60 & $\begin{array}{l}\text { Serious violations } \\
\text { frequent, or many } \\
\text { continuing minor } \\
\text { deviations with } \\
\text { shutdowns possible }\end{array}$ & $\begin{array}{l}\text { Project payback 0-3 } \\
\text { years for projects with } \\
\text { continuing need }\end{array}$ & $\begin{array}{l}\text { Develop necessary } \\
\text { methodologies, processes, and } \\
\text { techniques in support of critical } \\
\text { mission objectives; acceptable } \\
\text { R\&D nisk }\end{array}$ & $\begin{array}{l}\text { Cannot meet mission } \\
\text { capability; or unique } \\
\text { capability in jeopardy }\end{array}$ & $\begin{array}{l}\text { Poor - operation/ mission } \\
\text { threatened or at nsk }\end{array}$ & $\begin{array}{l}\text { System failure likely, with } \\
\text { associated inability to meet } \\
\text { overall mission requirements }\end{array}$ & \\
\hline 70 & & & & & $\begin{array}{l}\begin{array}{l}\text { Critical - strategic facilities } \\
\text { inoperable }\end{array} \\
\end{array}$ & $\begin{array}{l}\text { System failure highly likely, with } \\
\text { associated loss of critical } \\
\text { strategic mission capability }\end{array}$ & \\
\hline 80 & & & & & & & \\
\hline
\end{tabular}




\section{PROJECT CAMP SCORING WORKSHEET}

Evaluation Instructions: 1. Copy the highest subcategory in each category into the designated block

2. Enter the subcategory value into the designated block

3. Transfer the highest subcategory of all and value to sheet 1 in the designated block

4. Transfer the next highest subcategory of all and value in Rating 1 of sheet 1

4. Repeat 4 for Rating 2 and 3

\begin{tabular}{|c|c|c|c|}
\hline \multicolumn{4}{|l|}{ 1. Health and Safety Rating Criteria } \\
\hline Subcategories & $\begin{array}{l}\text { Assigned } \\
\text { Value }\end{array}$ & Highest Rated Subcategory & $\begin{array}{c}\text { Subcategory } \\
\text { Value }\end{array}$ \\
\hline Compliance with orders and laws & 30 & Industrial safety & 50 \\
\hline
\end{tabular}

\begin{tabular}{|l|l|}
\hline Technological base (R\&D) & 20 \\
\hline
\end{tabular}

\begin{tabular}{|l|l}
\hline Industrial Hygiene & 30 \\
\hline
\end{tabular}

\begin{tabular}{|r|r}
\hline Industrial safety & 50 \\
\hline
\end{tabular}

\begin{tabular}{|l|r|}
\hline Fire Protection & 30 \\
\hline
\end{tabular}

\begin{tabular}{|l|r|}
\hline Health Physics & 20 \\
\hline
\end{tabular}

\begin{tabular}{|l|r|}
\hline Criticality & 20 \\
\hline
\end{tabular}

\begin{tabular}{|l|r|}
\hline Infrastructure & 40 \\
\hline
\end{tabular}

\begin{tabular}{|c|c|c|c|}
\hline Environment and Waste Manas & Rating Crit & & \\
\hline Subcategories & $\begin{array}{l}\text { Assigned } \\
\text { Value }\end{array}$ & Highest Rated Subcategory & $\begin{array}{c}\text { Subcategory } \\
\text { Value }\end{array}$ \\
\hline Compliance with orders and laws & $\overline{2}$ & Corrective measures & 50 \\
\hline
\end{tabular}

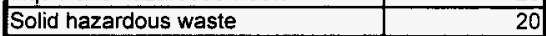

\begin{tabular}{|l|r|}
\hline Airborne pollutants & 20 \\
\hline
\end{tabular}

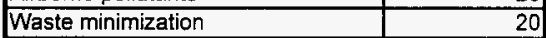

\begin{tabular}{|l|l}
\hline Environmental restoration & 30 \\
\hline
\end{tabular}

\begin{tabular}{|l|r}
\hline Corrective measures & 50 \\
\hline
\end{tabular}

\begin{tabular}{|l|r|}
\hline Infrastructure & 20 \\
\hline
\end{tabular}

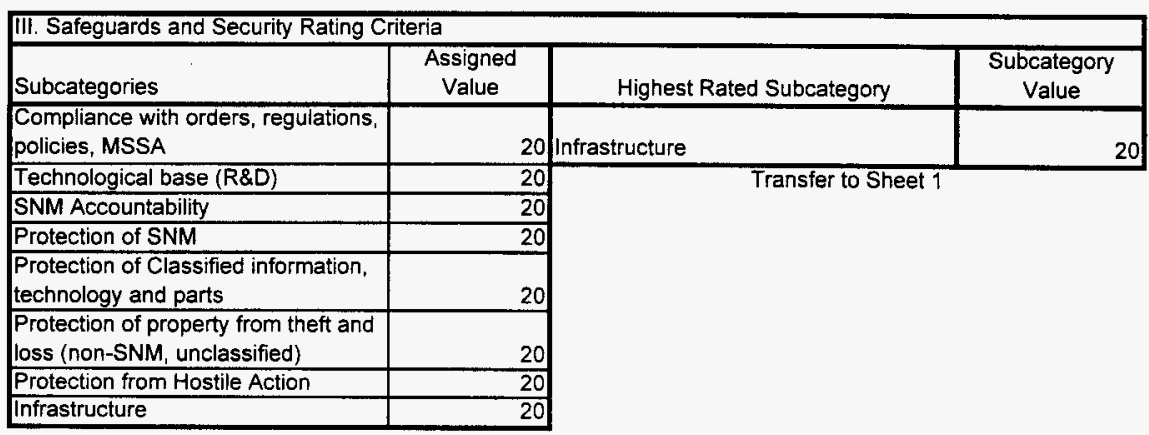


IV. Mission and Investment Rating Criteria

\begin{tabular}{|l|l}
\hline & Assigned \\
\hline
\end{tabular}

Subcategories

Compliance with orders, initiatives

and directives

Business benefits

Technological base (R\&D)

Mission capability, capacity, and

Quality

Asset condition

Infrastructure

National business

strategies/partnerships
Value

30 infrastructure

50

Subcategory

Value

Transfer to Sheet 1 


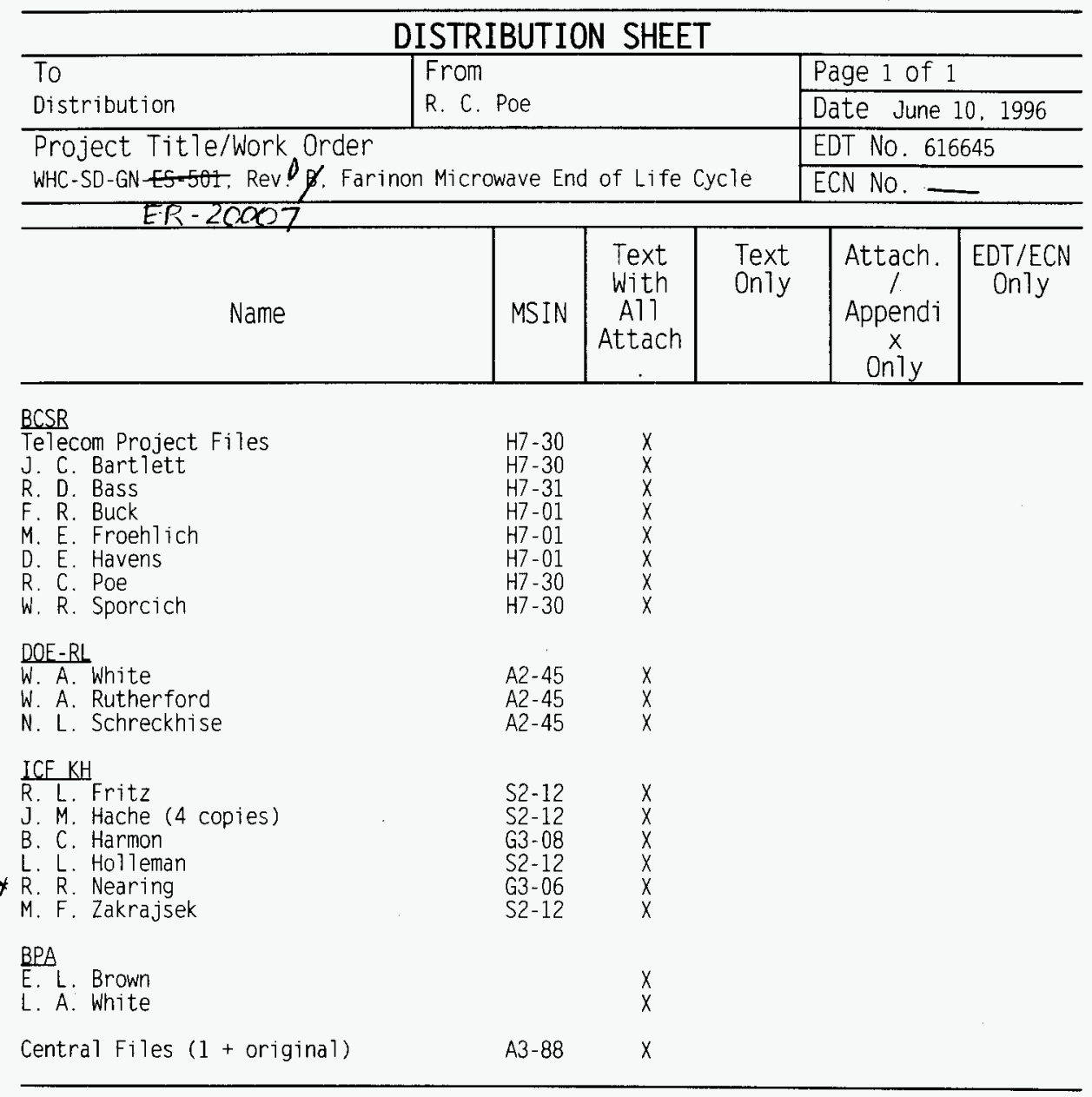

* Adianced Distribution 